九州大学学術情報リポジトリ

Kyushu University Institutional Repository

\title{
Triassic Ammonites from West Spitsbergen
}

Ishibashi, Takeshi

Faculty of Sciences, Kyushu University

Nakazawa, Ke i j i

Faculty of General education, Kinki University

https://doi.org/10.5109/1546557

出版情報：九州大學理學部紀要：Series D, Geology. 26 (3)，pp.215-241，1989-12-20. Faculty of Science, Kyushu University バージョン：

権利関係 : 
Mem. Fac. Sci., Kyushu Univ., Ser. D, Geol., Vol. XXVI, No. 3, pp. 215-241, text-figs. 1-6, tables 1-3, plates 35-40, December 20, 1989

\title{
Triassic Ammonites from West Spitsbergen
}

\author{
Takeshi IsHIBASHI and Keiji NAKAZAWA*
}

\begin{abstract}
This is a report of our biostratigraphical and paleontological study of Triassic ammonoids from the coastal area of Van Keulenfjorden, Wedel Jarlsberg Land in West Spitsbergen. Triassic ammonoids, 28 species of 17 genera, are described and their zones in Svalbard are discussed. They consist mainly of the Lower and Middle Triassic ammonites. The Upper Triassic ones are very rare in this area. Gyronites ef. plicatus is a representative of the Lower Scythian Vardebukta Formation in the Polahaugen section. The Lower Member of Botneheia Formation is correlated to the Lenotropites caurus Zone and "fossiliferous bed" associated with some species of Anagymnotoceras, Hollandites and Gymnotoceras of KoRchinskaYA $(1982,1986)$. The Middle Member yields Proarcestes and Ptychites. In the Upper Member, occurs poorly preserved ammonite, Nathorstites? sp. A. Another species of Nathorstites sp. found in the lower horizon of Kapp Toscana Group is probably Carnican.
\end{abstract}

\section{Introduction and Acknowledgments}

In 1986, the Japanese team made a geological exploration on the upper Paleozoic to the lower Mesozoic sequences in West Spitsbergen as a joint project with the Norwegian Polar Research Institute (NP). Detailed geological columnar sections were established from the Carboniferous to the Lower Jurassic in the Reinodden area and from the Permian to the Triassic in the Ahlstrandodden area; both localities are situated along the south coast of Van Keulenfjorden in Wedel Jarlsberg Land (Figs. 1-3). A stratigraphical and paleontological study had not been fully made there. The results of the survey have recently been summarized by NAKAzaWA et al. and are now in press. Many Triassic molluscan fossils have been collected through the survey. The present paper reports the occurrence of the Triassic ammonoid fossils, and discusses the ammonoid zones in the study area together with the description of the species. The senior author is primarily responsible for the paleontological description and the other of us summarizes stratigraphical description and correlation in this study.

The project was accomplished by a kind support of the Norwegian Polar Research Institute and the Kyoikusha Ltd., Tokyo. Professor Emeritus T. TATsumi of the University of Tokyo, Dr. Y. OHTA and Mr. T. S. WINsNES of NP gave one of us $(\mathrm{KN})$ instructive suggestions for the joint project. The field survey and fossil-collection were made in cooperation with Mr. H. Suzukr of Doshisha University, Dr. F. KumoN of Shinshu University, and Mr. E. H. SigGERUD of Bergen University. Dr. M. V. KoRCHINSKAYA of "SEVMORGEO" in Leningrad kindly

Manuscript received August 3, 1989

* Faculty of General Education, Kinki University 
offered us her valuable publications. Professor Emeritus T. Matsumoto of Kyushu University critically read the manuscript. We wish to express our cordial thanks to all these persons.

All the specimens with prefix JM are deposited at the Department of Geology and Mineralogy, Faculty of Science, Kyoto University. For the taxonomy of ammonoid families we follow the scheme proposed by Tozen (1981).

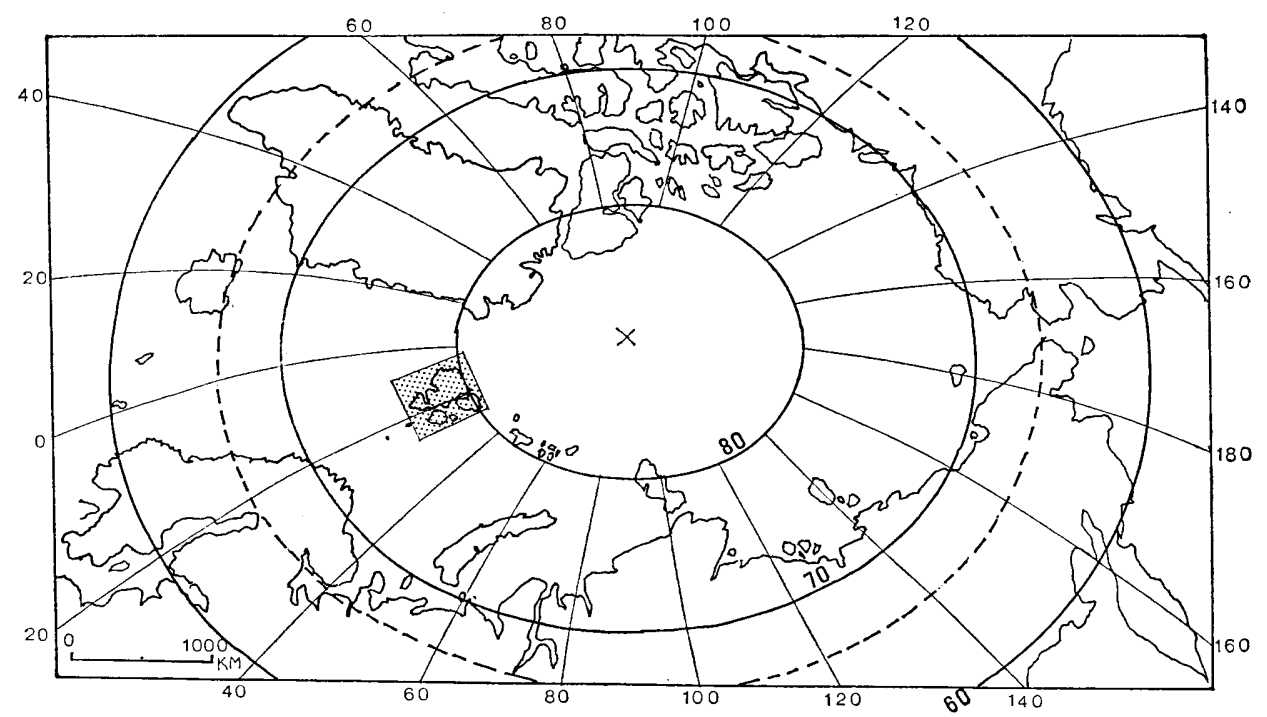

Fig. 1. Index map of Svalbard in the Arctic region.

\section{Stratigraphy}

The standard classification of the Triassic System in Svalbard was proposed by BUCHAN et al. (1965), which is adopted in the present paper (Table 1). The Triassic strata are grouped into two, the Sassendalen Group, below, and the Kapp Toscana Group, above. The latter group was originally named as a formation, but later upgraded in rank by FLOOD et al. (1971). The Sassendalen Group is subdivided into three formations, the Vardebukta, Sticky Keep, and Botneheia Formations, in ascending order. The Kapp Toscana Group is classified into two formations, the Tschermakfjellet Formation and the overlying De Geerdalen Formation around Isfjorden, but this division can not be exactly applied in the type locality, Kapp Toscana, in the Ahlstrandodden area (BUCHAN et al., 1965).

(1) Sassendalen Group

The Sassendalen Group as a whole consists of shale, thinly alternating shale and calcareous siltstone or very fine-grained calcareous sandstone. Arenaceous limestone is sometimes intercalated. Coarse-grained clastic rocks, such as coarsegrained sandstone and conglomerate, are subordinate.

The Vardebukta and Sticky Keep Formations are divisible into a finergrained lower member, rich in shale, and a coarser-grained upper member, predominant in sandstone as shown in Figs. 4 and 5. 


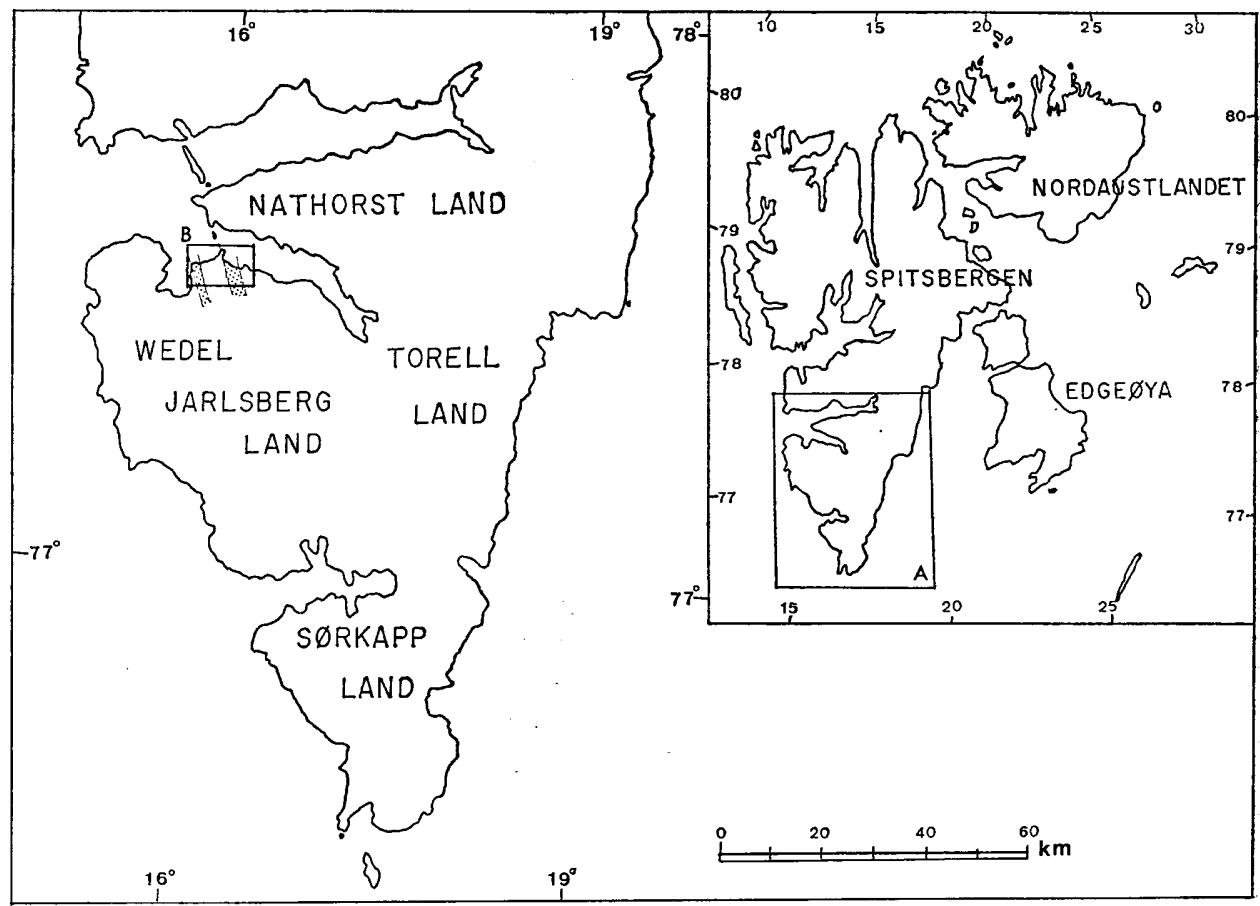

Fig. 2. Index map (A) showing major islands of Svalbard and (B) geographical location of the study area in West Spitsbergen.

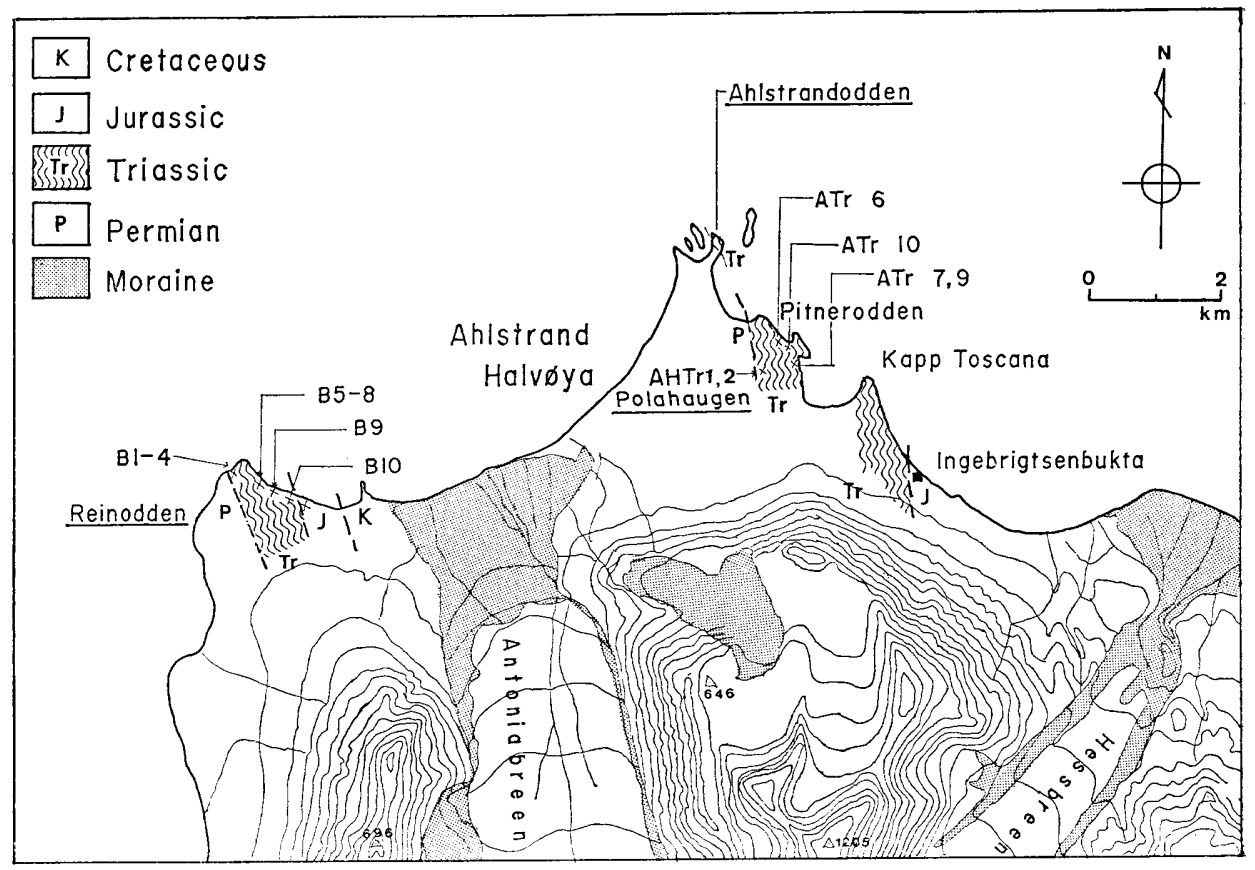

Fig. 3. Map showing localities of Triassic ammonites in Wedel Jarlsberg Land. 
The Botneheia Formation is characterized by a common occurrence of phosphatic nodules. The lower part is composed mostly of shale and separated as Lower Member. The rest of the formation is dominated by sandstone, and classified into Middle and glauconitic Upper Members. On the basis of lithofacies characteristics, the Vardebukta and Sticky Keep Formations are considered to make a sedimentary cycle changing the facies from a distal deep shelf one to a shallower deep shelf through an offshore bar facies of MøRK et al. (1982). The Botneheia Formation is supposed to have been deposited in a distal deep shelf environment, changing upward into a deltaic one.

Table 1. Stratigraphic division of the Carboniferous-Cretaceous sequence in Spitsbergen

(Nakazawa et al., MS)

\begin{tabular}{|c|c|c|c|c|}
\hline \multicolumn{2}{|c|}{$\begin{array}{l}\text { Cretaceous } \\
\text { Jurassic }\end{array}$} & $\begin{array}{l}\text { Adventalen } \\
\text { Group }\end{array}$ & \multicolumn{2}{|c|}{ Janusfjellet Formation } \\
\hline & \multirow[b]{2}{*}{ Upper } & \multirow{2}{*}{\multicolumn{3}{|c|}{ 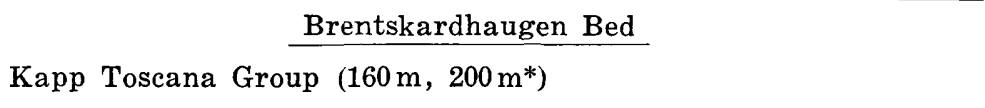 }} \\
\hline \multirow{8}{*}{ 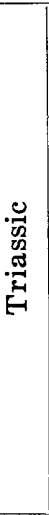 } & & & & \\
\hline & \multirow{3}{*}{ Middle } & \multirow{7}{*}{$\begin{array}{l}\text { Sassendalen } \\
\text { Group }\end{array}$} & \multirow{3}{*}{$\begin{array}{l}\text { Botneheia } \\
\text { Formation }\end{array}$} & Upper Member $(25 \mathrm{~m}$, \\
\hline & & & & Middle Member $(90 \mathrm{~m}, 220 \mathrm{~m})$ \\
\hline & & & & Lower Member $(60 \mathrm{~m}$, \\
\hline & & & Sticky Keep & Kaosfjellet Member $(268 \mathrm{~m}, 124 \mathrm{~m})$ \\
\hline & Towor & & Formation & Iskletten Member $(85 \mathrm{~m}, 83 \mathrm{~m})$ \\
\hline & LOWEI & & Vardebukta & Siksaken Member $(68 \mathrm{~m}, 55 \mathrm{~m}+)$ \\
\hline & & & Formation & Selmaneset Member $(35 \mathrm{~m}, ?)$ \\
\hline$\underset{\pi}{\tilde{\pi}}$ & $\begin{array}{l}\text { Upper } \\
\text { Middle }\end{array}$ & $\underset{\text { Group }}{\text { Tempelfjorden }}$ & $\begin{array}{l}\text { Kapp Starostin } \\
\text { Formation }\end{array}$ & $\left.\left.\begin{array}{cc}\text { Unit } & \mathrm{H} \\
\mid & \\
\text { Unit } & \mathrm{A}\end{array}\right\}(300 \mathrm{~m}), \begin{array}{cc}\text { Unit } \\
\vdots \\
\text { Unit } & 1\end{array}\right\}(250 \mathrm{~m})$ \\
\hline D. & Lower & Gipsdalen & Gipshuken Form & ation $(80 \mathrm{~m})$ \\
\hline & Howet & Group & Reinodden Form & ation $(170 \mathrm{~m})$ \\
\hline & iferous & Billefjorden & Vegard Formati & n $(90 \mathrm{~m})$ \\
\hline & Dorititerous & Group & Orustdalen Form & lation $(390 \mathrm{~m}+)$ \\
\hline
\end{tabular}

Metres in parentheses are thickness in the Reinodden (left) and Ahlstrandodden (right) areas, respectively.

( $*$ from BUCHAN et al., 1965)

\section{(2) Kapp Toscana Group}

The lowermost $50 \mathrm{~m}$ of the Kapp Toscoana Group in Reinodden, consists mostly of black fissile shale. This part may be correlated with the Tschermakfjellet Formation in Isfjorden. It is followed by alternating beds of varicolored, glauconitic sandstone and shale. The Kapp Toscana Group as a whole represents a regressive phase. In the Ahlstrandodden area it changes lithofacies from a neritic one to an estuary or fluvial one. 


\section{Stratigraphic Occurrence of Fossils and Bio-zones}

Megafossils of the Triassic marine strata are represented by molluscs, namely, ammonoids and bivalves. They occur at various horizons throughout the Sassendalen Group, but are very rarely found in the Kapp Toscana Group.

(1) Vardebukta Formation

The lower member of the Vardebukta Formation, the Selmaneset Member, is fully exposed along the coast of Reinodden, but completely concealed in the Ahlstrandodden area. The lower part of the member is characterized by Claraia stachei (BITTNER). KORCHINSKAYA and VAVILOV (1987) recently reported Otoceras boreale SPATH and Glyptophiceras sp. in association with Claraia stachei and Myalina (=Promyalina?) sp. The horizon is indicated as Hor. V 2 in Fig. 5 of the present paper. The upper part of the member is common in Promyalina degeeri (LUNDGREN), P. cf. groenlandica NEWELL and Unionites, whereas Claraia stache $i$ is very rare.

The Siksaken Member above the Selmaneset Member in Reinodden contains several coquinoid layers which yield Promyalina degeeri, Unionites fassaensis (WISSMANN), and Leptochondria minima KIPARIsova. The horizon of Vavilovites spitsbergensis KORCHINSKAYA, which was first reported by GAZDZICKI and TRAMMER (1977) as V. aff. sverdrupi TOZER, is located in the middle of this member (Hor. V5 of Fig. 5). At Polahaugen in the Ahlstrandodden area, Gyronites cf. plicatus (TOZER), Vavilovites? sp., Eumorphotis multiformis BITTNER, Promyalina spp., Unionites fassaensis, Leptochondria minima, and Neoschizodus cf. laevigatus (ZIETHEN) have been collected from the limestone coquina (AHTr1 and 2 of Fig. 4).

(2) Sticky Keep Formation

Megafossils occur only sporadically in the Sticky Keep Formation. A nearly smooth, rather evolute ammonite shell collected by WINSNES from the Iskletten Member and kept at Geology Museum, University of Oslo (No. A 26559) is most probably identical with Xenoceltites. The horizon is considered to be around Hor. SK0b of the present paper (Fig. 5). A coquinoid limestone near the base of the Kaosfjellet Member in Reinodden (SK1) contains Leptochondria minima and "Pecten" touli (LuNDGREN), and that of Ahlstrandodden (ATr5) has Promyalina degeeri, Unionites fassaensis, Leptochondria minima, and Neoschizodus cf. laevigatus. No ammonoids have been obtained from this member.

(3) Botneheia Formation

Ammonoid fossils are most common in this formation throughout the Triassic in the study area, particularly, in the lower half. In the Reinodden area, many specimens have been collected from three horizons (B 1,3 and 4) of the Lower Member, and one horizon (B 5) of the Middle Member, but only one indeterminable specimen from the lowermost horizon of the Upper Member (B 10a) and several, poorly preserved ones from the uppermost horizon (B 10b) wre procured. In the Ahlstrandodden area, ammonoid shells are commonly found at three horizons of the lower part of the formation (ATr 6, 7 and 9), but only one specimen was detected from the upper part (ATr 10). 


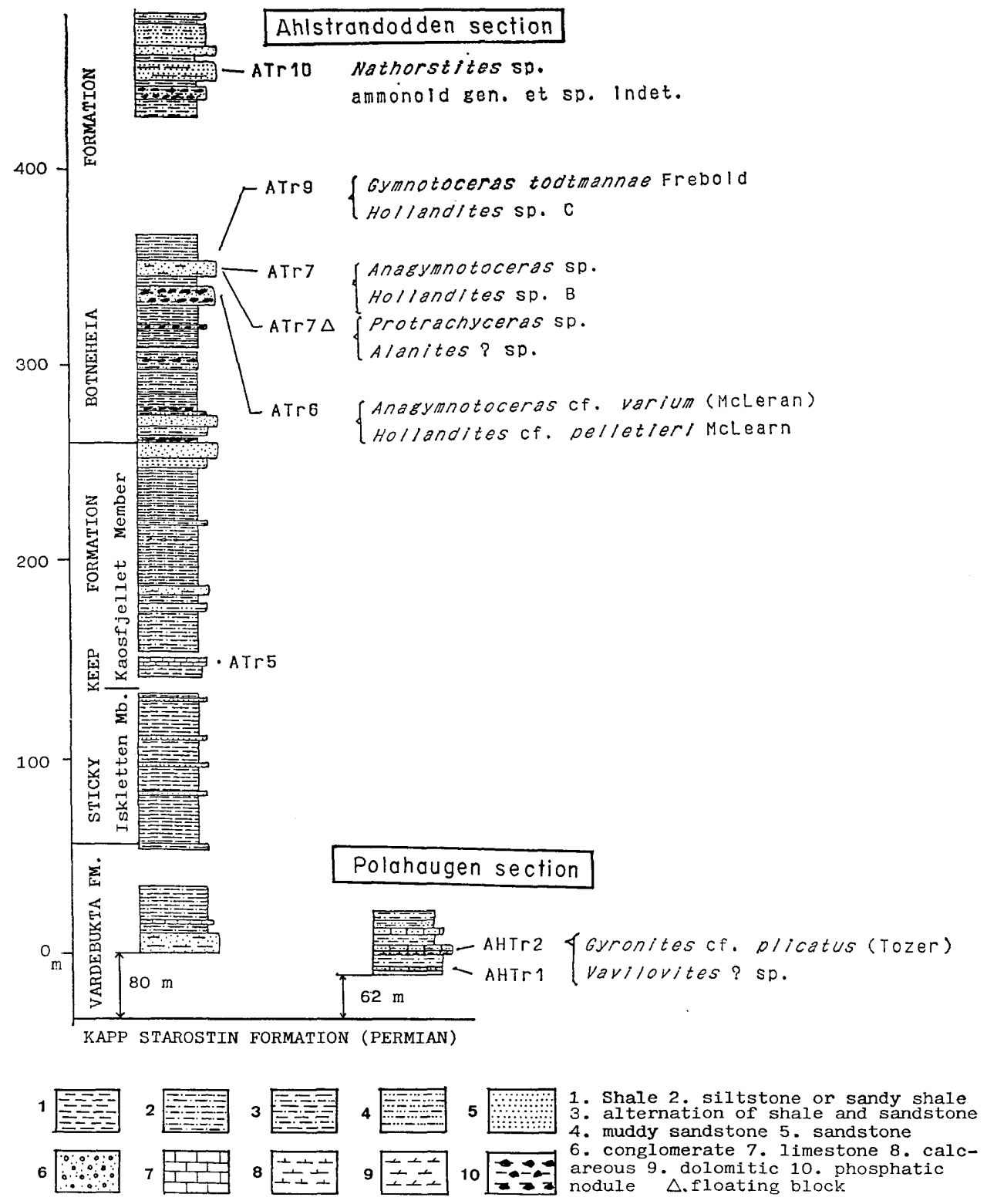

Fig. 4. Stratigraphic section indicating the horizons of Triassic ammonites and bivalves in Ahlstrandodden and Polahaugen sections. (adapted from NAKAzAwA et al., MS)

\section{(4) Kapp Toscana Group}

Only a single specimen has been obtained from the basal part of the Kapp Toscana Group in Reinodden (KT-1). No marine fossils could be detected from this group in the Ahlstrandodden area. 


\section{Discussion of Correlation}

The ammonoid fossils collected are listed in Table 2. The biostratigraphy of the Triassic in Svalbard based mainly on ammonites was discussed by SPATH (1921), TOZER and PARKer (1968), KORChinskayA (1982, 1986) and others. In the following lines, the comparison of ammonite zones in the study area with those of Korchinskaya is mainly discussed (Table 3). The lower part of the Selmaneset Member of the Vardebukta Formation is correlated with the Otoceras boreale Zone by a discovery of Otoceras and Glyptophiceras as mentioned already. The Vavilovites bed in the middle of the Siksaken Member in Reinodden and Gyronites bed in Polahaugen are compared to the Vavilovites spitsbergensis Zone. The beds with Promyalina and Unionites between the two zones mentioned above are, therefore, referred to as the Proptychites rozenkrantzi Zone, although the Promyalina-Unionites fauna is found in still higher beds than Vavilovites Zone.

The Otoceras boreale Zone was first placed below the Claraia stachei bed and correlated with both the Otoceras concavum Zone and the O. boreale Zone in Arctic Canada by KorchinsKaya (1982), but later the lower half of the Ophiceras commune Zone was also included in the Boreale Zone in Svalbard by her (1986), because in Svalbard $O$. boreale usually coexists with Claraia stachei. NAKAZAWA et al. (1987) considered that the Boreale Zone was correlated with the Upper Griesbachian Ophiceras tibeticum Zone in Kashmir, India taking also the conodont fossils into consideration.

The Iskletten Member of the Sticky Keep Formation is probably referred to as the Lower Olenekian (Smithian) Arctoceras blomstrandi Zone based on the occurrence of Xenoceltites? sp. from the upper part of the member. No diagnostic fossils have been obtained from the overlying Kaosfjellet Member, but according to Hatleberg and CLARK (1984), the lower part of the member yields Neogondolella nevadensis (MÜLLER) in Reinodden, and N. homeri (BENDER), N. collinsoni SolIEN, $N$. triangularis (BENDER), and $N$. jubata (SwEET) in Pitnerodden.*. This conodont assemblage is quite identical to that of the Early Spathian (Late Olenekian) Collinsoni Zone of SwEET (1988). HATLEBERG and ClARK (op. cit.) reported Neogondolella mombergensis (TATGE), and N. regale Mosher from the uppermost horizon of the Kaosfjellet Member in Reinodden, and the top of the Sticky Keep Formation may reach Anisian in age.

The fauna of the Lower Member of the Botneheia Formation in Reinodden (Hor. B1 and 2) comprises Lenotropites cf. tardus MCLEARN, L. cf. caurus (McLearN), Grambergia ovinus (MCLEARN), Paracrochordiceras sp., Paradanubites sp., etc. This fauna is quite identical with that of the Lower Anisian Lenotropites caurus Zone. In the highest horizon of the Lower Member in Reinodden (B4) occur Hollandites orientalus BYTSCHKov et KIPARISOva, Anagym-

\footnotetext{
* This conodont assemblage was referred to occur in the Iskletten Member by HATLEBERG and ClARK, but according to the detailed survey by NAKAZAWA et al. (MS), the boundary of the Iskletten/Kaosfjellet Member should be placed around $240 \mathrm{~m}$ horizon of HATLEBERG and CLARK's column (1984, fig. 7), and the fossil horizons of above-mentioned species are actually included in the Kaosfjellet Member.
} 


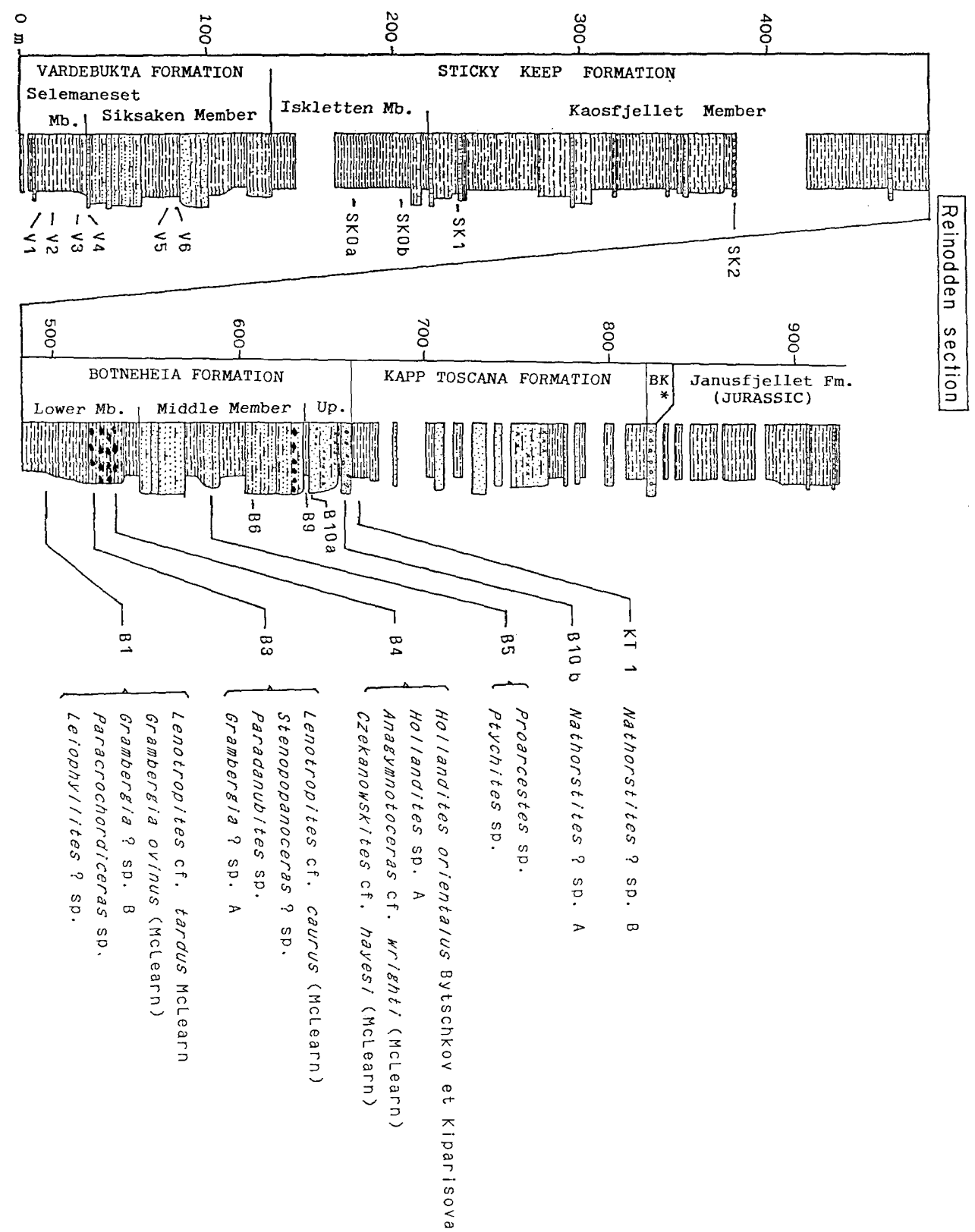

Fig. 5. Stratigraphic section indicating the horizons of Triassic ammonites and bivalves in Reinodden section.

*BK: Brentskadhaugen Bed

(adapted from NAKAZAWA et al., MS)

notoceras cf. wrighti (MCLEARN), Czekanowskites cf. hayesi (MCLEARN) etc.

The equivalent horizons in Pitnerodden (ATr6, 7 and 9) yield Anagymnotoceras cf. varium (MCLEARN), Gymnotoceras todtmannae FrEBOLD, Hollandites cf. pelletieri MCLEARN and others. The assemblage of all these species is very similar 
Table 2. Table showing the stratigraphic occurrence of ammonoid species.

\begin{tabular}{|c|c|c|c|c|c|c|c|c|}
\hline \multirow[b]{3}{*}{ Species } & \multicolumn{2}{|c|}{$\begin{array}{l}\text { Var- } \\
\text { debukta }\end{array}$} & \multirow{2}{*}{$\begin{array}{l}\text { SK } \\
\text { IS }\end{array}$} & \multicolumn{2}{|c|}{ Botneheia } & \multicolumn{2}{|c|}{ Formation } & \multirow[t]{2}{*}{ KT } \\
\hline & S1 & S2 & & Bl 1 & Bl 2 & $\mathrm{Bm}$ & $\mathrm{Bu}$ & \\
\hline & $\stackrel{N}{p}$ & 葛 & 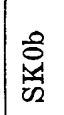 & $\bar{m} \mathscr{m}$ & 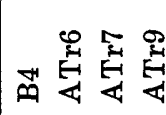 & 色 & 总 & $\overrightarrow{\mid}$ \\
\hline $\begin{array}{l}\text { Otoceras boreale SPATH } \\
\text { Glyptophiceras cf. nielseni SPATH }\end{array}$ & $*$ & & & & & & & \\
\hline $\begin{array}{l}\text { Vavilovites spitsbergensis } \\
\text { KORCHINSKAYA } \\
\text { Gyronites cf. plicatus (TOZER) } \\
\text { Vavilovites? sp. }\end{array}$ & & * & & & & & & \\
\hline Xenoceltites? sp. & & & * & & & & & \\
\hline $\begin{array}{l}\text { Lenotropites cf. tardus MCLEARN } \\
\text { Lenotropites cf. caurus (MCLEARN) } \\
\text { Stenopopanoceras? sp. } \\
\text { Grambergia ovinus (MCLEARN) } \\
\text { Grambergia? sp. } \\
\text { Leiophyllites? sp. } \\
\text { Paradanubites sp. } \\
\text { Paracrochordiceras sp. }\end{array}$ & & & & $\begin{array}{ll}* & \\
& * \\
& * \\
* & \\
* & * \\
* & \\
* & \\
* & \end{array}$ & & & & \\
\hline $\begin{array}{l}\text { Hollandites orientalus BYTSCHKOV } \\
\text { \& KIPARISOVA } \\
\text { Hollandites cf. pelletieri } \\
\text { (MCLEARN) } \\
\text { Hollandites sp. A } \\
\text { Hollandites sp. B } \\
\text { Anagymnotoceras cf. wrighti } \\
\text { (McLEARN) } \\
\text { Anagymnotoceras cf. varium } \\
\text { (MCLEARN) } \\
\text { Anagymnotoceras sp. } \\
\text { Hollandites sp. C } \\
\text { Protrachyceras sp. } \\
\text { Alanites? sp. } \\
\text { Czekanowskites cf. hayesi } \\
\text { (MCLEARN) } \\
\text { Gymnotoceras todtmannae } \\
\text { FREBOLD }\end{array}$ & & & & & 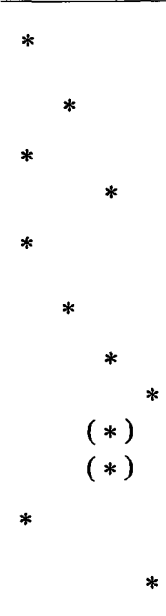 & & & \\
\hline $\begin{array}{l}\text { Proarcestes sp. } \\
\text { Ptychites sp. } \\
\text { Nathorstites sp. }\end{array}$ & & & & & & * & & \\
\hline $\begin{array}{l}\text { Nathorstites? sp. A } \\
\text { Nathorstites? sp. B }\end{array}$ & & & & & & & $*$ & \\
\hline
\end{tabular}

S1: lower horizon of Selmaneset Member, S2: upper horizon of Selmaneset Member, Is: Iskletten Member, Bl 1: lower horizon of Lower Member of Botneheia Formation, Bl 2: upper horizon of Lower Member, Bm: Middle Member, Bu: Upper Member, KT: Kapp Toscana Group, SK: Sticky Keep Formation, *: in situ, (*): floating block. 
to the Anagymnotoceras, Hollandites, Gymnotoceras assemblage of the Middle Anisian age of KoRCHINSKAYA (1982).

Proarcestes sp.-Ptychites sp. bed of the Middle Member in Reinodden is referred to as the Lower Ladinian Ptychites nanuk Zone.

The upper part of the Middle Member (B6 and 9) is characterized by the common occurrence of Daonella frami KITTL and D. degeeri BoEHM. The both species are reported from the Lower Ladinian Ptychites nanuk Zone as well as the Upper Ladinian Nathorstites meconnelli Zone. Judging from the biostratigraphic situation, the Daonella beds are considered to belong to the Mcconnelli Zone, however. Nathorstites sp. from the upper part of the Botneheia Formation in Pitnerodden (ATr 10) is somewhat similar to N. lindstroemi (WHITEAVES) illustrated by PoPOV (1961) from the Ladinian of Kolyma. This horizon may be correlated with the Daonella beds in Reinodden.

Nathorstites? sp. A from the uppermost part of the Botneheia Formation (B 10b) is more similar to N. tenuis STOLLEY than to N. mcconnelli (WhiteAVES) in its laterally compressed shell. Nathorstites? sp. B from the basal horizon (KT 1) of the Kapp Toscana Group is somewhat similar to N. gibbosus SToLleY reported by KoRCHINSKAYA (1982) from the Kapp Toscana Group in the northern part of Edgeøya. KoRCHINSKaYA et al. (1967) critically examined the Nathorstites fauna and other faunas in Svalbard, and came to the conclusion that the Carnian was characterized by $N$. tenuis, N. gibbosus and Halobia zitteli LINDSTROEM, while the Ladinian is distinguished by the occurrence of Daonella frami, $D$. degeeri and ammonoids of the Middle Triassic aspects, such as, Ptychites, Monophyllites, Protrachyceras, and others. McLearN (1947) favoured the Ladinian age of the Nathorstites fauna including $N$. meconnelli in British Columbia, and KoRCHINsKaYA (1982) placed the Ladinian/Carnian boundary at Mcconnelli/Tenuis Zone boundary. Accordingly, the top of the Botneheia Formation in Reinodden has a possibility to reach Carnian in age, but the specimens are too imperfect to give any definite conclusion.

\section{Systematic Paleontology}

Order Ceratitida HYATT, 1884

Superfamily Noritaceae KARPINSKY, 1889

Family Meekoceratidae WAAGEN, 1895

Subfamily Meekoceratinae, WAAGEN, 1895

[=Gyronitinae WAAGEN, 1895; Kyamatitinae WAAGEN, 1895]

Genus Gyronites WAAGEN, 1895

[=Prionolobus WAAGEN, 1895; ?Gyrolecanites SPATH, 1934; ?Catalecanites SPATH, 1934]

Type species.-Gyronites frequens WAAGEN, 1895.

Gyronites cf. plicatus (TOZER)

Pl. 35, Figs. 1a-b and 2; Text-fig. 6. 
Table 3. Correlation of bio-zones or fossiliferous beds in Arctic Canada, Svalbard, and study area

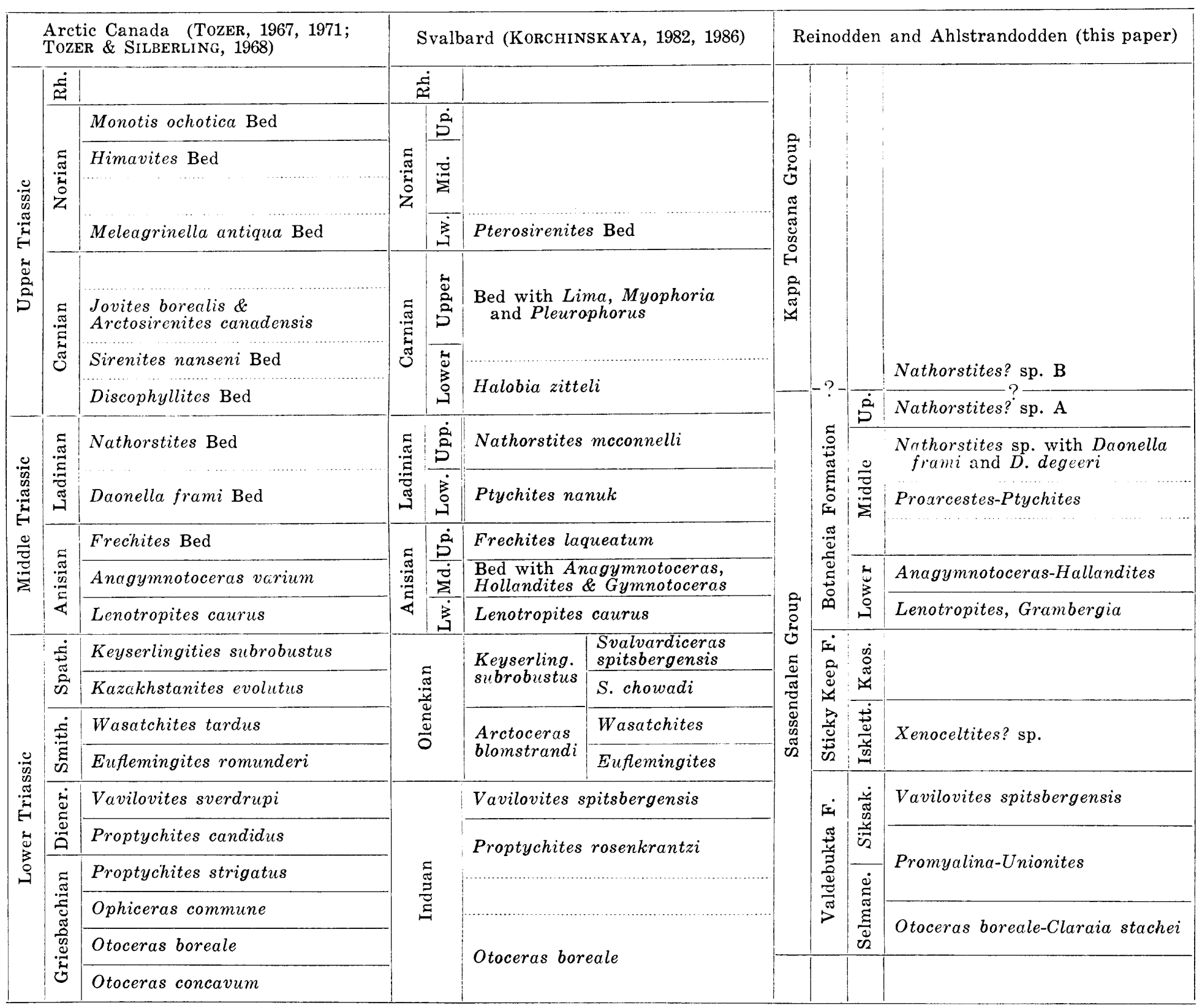


Compare.-

1961. Prionolobus plicatus Tozer: Geol. Surv. Canada, Mem., 316, p. 49-50, pl. 20, nos. 4a-c, 5a-c.

1986. Prionolobus cf. plicatus TOZER; KoRChINSKAYA: Biostrati. sequence in Spitsbergen, p. 85-86, pl. 6, figs. 3a, $3 \mathrm{~b}$; pl. 7, figs. 1a, $1 \mathrm{~b}, 4$.

Material.-Two specimens, of which one (JM11551) is $115 \mathrm{~mm}$ in diameter and $24 \mathrm{~mm}$ in width, the other (JM11552) is $130 \mathrm{~mm}$ in diameter and $28 \mathrm{~mm}$ in width.

Description.-Shell rather large, involute discoidal, laterally compressed with very acute venter. Flank gently convex and smooth without ribs and nodes or tubercles. Outer whorl embracing almost all part of inner whorl, gradually increases its height. Umbilicus rather narrow, about $20 \%$ of diameter with abruptly bent shoulder. Septa ceratitic with main three saddles.

Remarks.-The present species was originally described by TOZER (1961) under the generic name of Prionolobus from the Blind Fiord Formation in Axel Heiberg Island of Arctic Canada. After this genus was considered by him (1981) as synonym with Gyronites established by WAAGEN (1895). The holotype has wide and low radial ribs on the inner part of flank, without attaining to the middle of flank. These ribs are not shown in our specimens probably owing to secondary compression. The horizon of this species is correlated to the upper Lower Scythian.

Other specimens described by KoRchINSKAYA (1986) were collected from the Vardebukta Formation of the Reinodden Section of the same area (Van Keulenfjorden). The present specimens are associated with Vavilovites? sp. and have almost the same characteristics as KORCHINSKAYA's in the figures of plates which have discoidal whorl, with slightly convex smooth side.

The stratigraphic horizon of Gyronites cf. plicatus in Spitsbergen is included in the Vavilovites spitsbergenensis Zone (Lower Scythian) by KoRCHINSKAYA (ditto). The present specimens associate with some bivalves and brachiopods (NAKAZAWA et al., MS). Those Spitsbergen specimens are probably conspecific with the holotype of Canada.

Occurrence.-The material was collected from the horizon AHTr2 of the Vardebukta Formation of Polahaugen section, West Spitsbergen. The Vavilovites spitsbergenensis Zone in the Lower Scythian.

Superfamily Noritaceae KARPINSKY, 1889

Family Meekoceratidae WAAGEN, 1895

Subfamily Proptychitidae WAAGEN, 1895

Genus Vavilovites TozER, 1971

[=Vavilovites (Tompoproptychites) VAVILOV and ZACHARov, 1976]

Type species.-Paranorites sverdrupi TozER, 1963.

Vavilovites? sp.

Pl. 35, Figs. 3a-b.

Material.-An incomplete whorl of large specimen (JM11553).

Descriptive remarks.-The present specimen is half of an outer whorl, but 


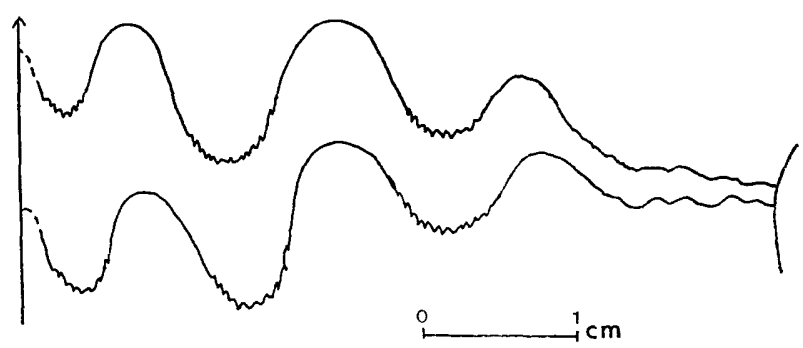

Fig. 6. Suture-line of Gyronites cf. plicatus (TozER)

(Pl. 35, Figs. 1a-b)

some charactes are recognized. The shell is considerably large, more than $240 \mathrm{~mm}$ in diameter and $40 \mathrm{~mm}$ in width, and has rather involute, discoidal and laterally compressed with flat sides. The venter is very acute. The umbilicus is presumably of moderate size. Suture is not preserved. The specimen is incomplete enough to confidently assign it to the genus Vavilovites.

Vavilovites (Vavilovites) spitsbergensis was described from the Vardebukta Formation of Reinodden section by KorchinskaYA (ibid.). She established the $V$. spitsbergenensis Zone in the Lower Scythian of Spitsbergen and correlated with the V. sverdrupi Zone of Arctic Canada.

Occurrence.-Vavilovites? sp. is collected from the Verdebukta Formation (AHTr2) of Polahaugen section, West Spitsbergen. Lower Scythian.

Superfamily Dinaritaceae MoJsisovics, 1882

Family Dinaritidae MoJsisovics, 1882

[=Dagnoceratinae SPATH, 1934]

Subfamily Khvalynitinae SHEVYREV, 1968

Genus Alanites SHevyrev, 1968

Type species.-Alanites visendus SHEVYREv, 1968.

Alanites ? sp.

Pl. 40, Fig. 8

Material.-Only one specimen (JM11614) collected from the block near the horizon ATr7.

Remarks.-The specimen has a half of shell, about $90 \mathrm{~mm}$ in diameter. Shell is rather evolute and increases gradually its height. The present specimen is too poorly preserved for the definite determination of generic and specific names. Alanites was established by SHEVYREV (1968) on the basis of the specimen collected from the Paratrachyceras trinodosus Zone of the Caucasus.

\section{Explanation of Plate 35}

Figs. 1a, 1b and 2. Gyronites ef. plicatus (Tozer) ................ 224

Figs. $1 \mathrm{a}$ and $1 \mathrm{~b}(\mathrm{JM} 11551) \times 1$

Fig. 2 (JM11552) $\times 0.5$. Horizon: AHTr2

Figs. $3 a$ and $3 b$. Vavilovites? sp. ........................... 225

(JM11553) $\times 0.5$. Horizon: AHTr2 


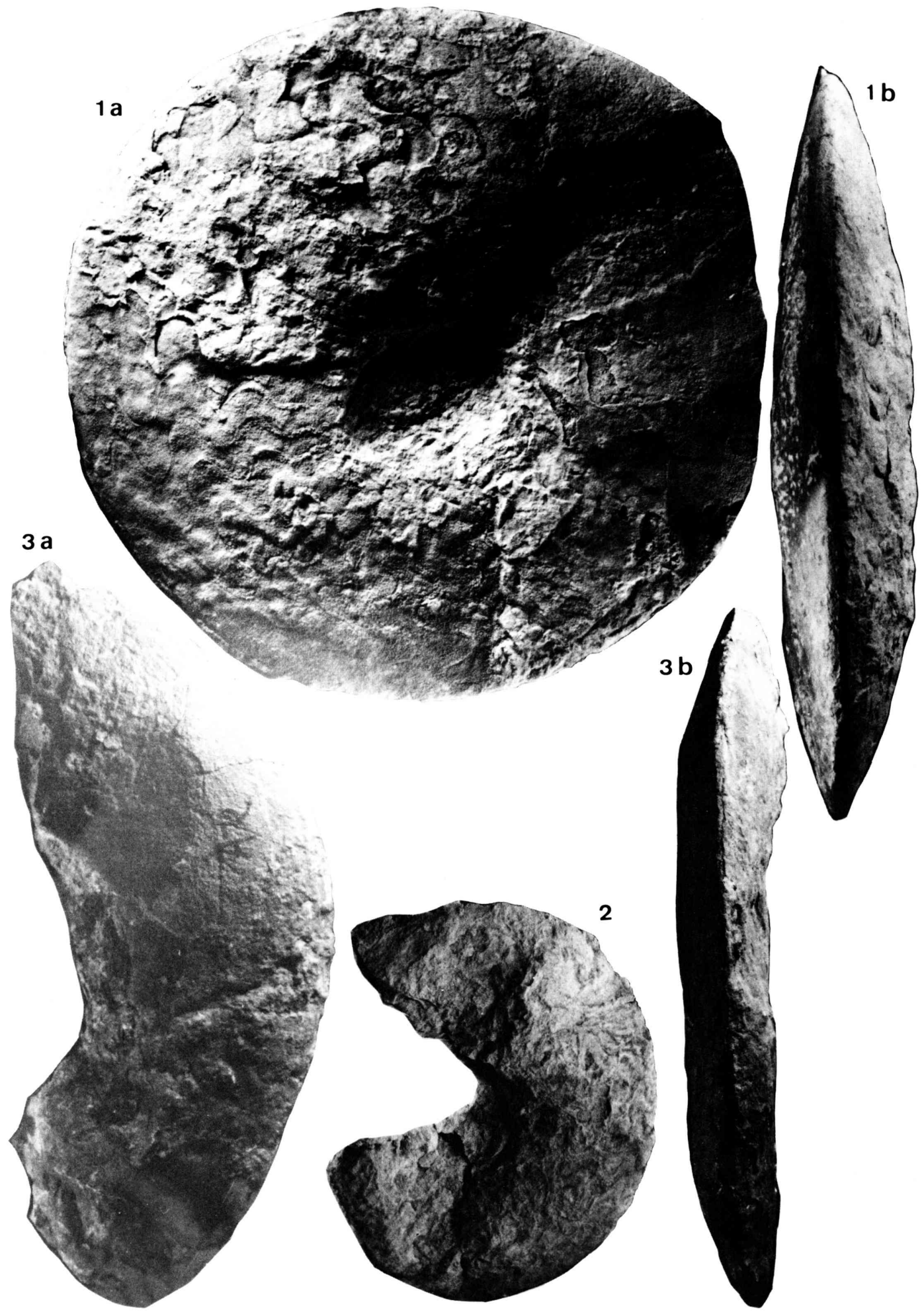

T. Ishibashi \& K. NAkazawa: Triassic Ammonites from Spitsbergen 

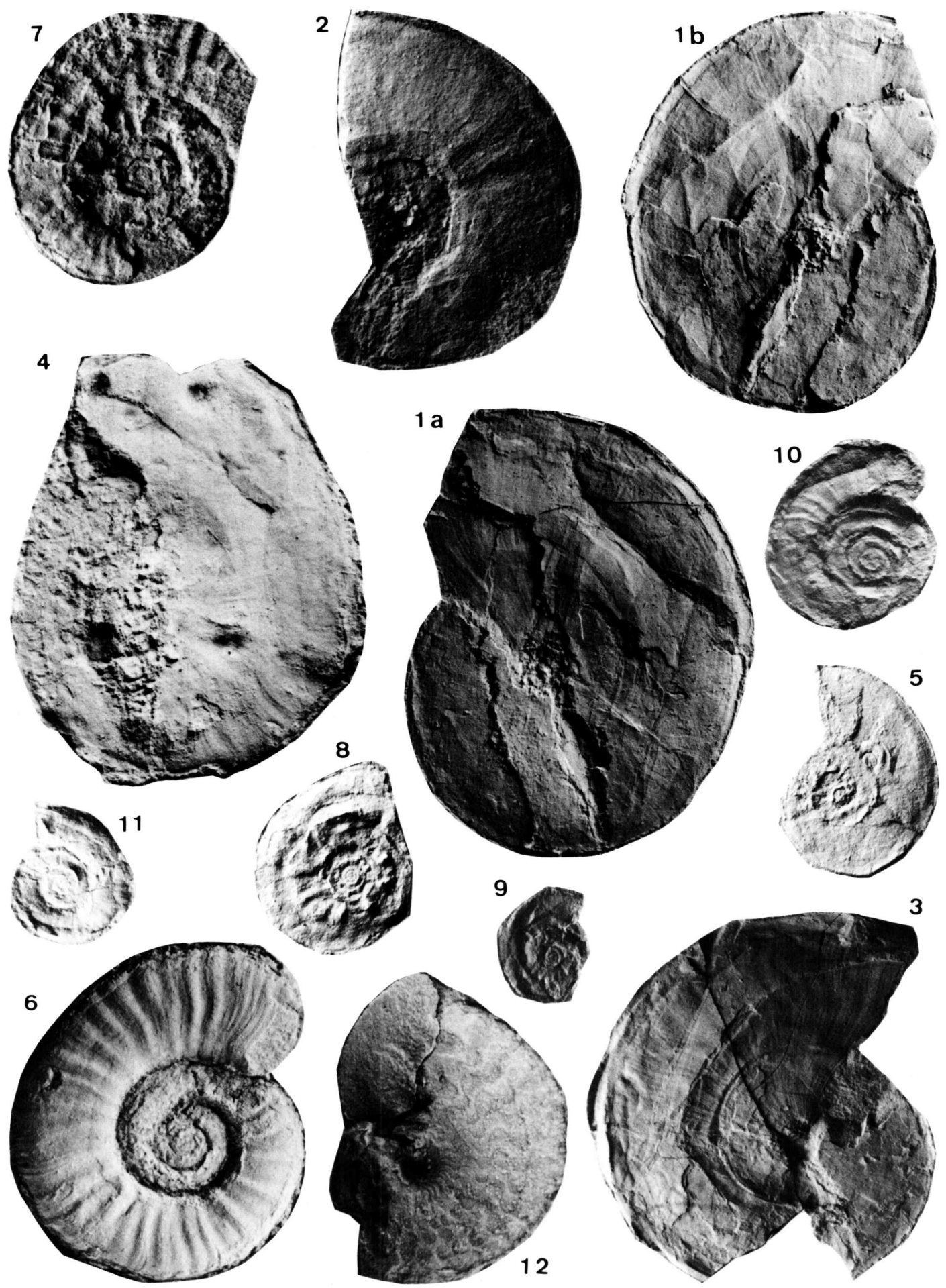

T. Ishibashi \& K. NAKazawa: Triassic Ammonites from Spitsbergen 
Occurrence.-The specimen was found in the block collected from near horizon ATr7 of Ahlstrandodden section, so the exact stratigraphic horizon is unknown. It is associated with Protrachyceras sp.

Superfamily Megaphyllitaceae MoJsisovics, 1896

Family Parapopanoceratidae TozER

Genus Stenopopanoceras PoPOV, 1961

Type species.-Stenopopanoceras mirabile Popov, 1961.

Stenopopanoceras? sp.

Pl. 37, Fig. 15.

Material.-A fragmentary specimen (JM11579). It slightly exceeds $30 \mathrm{~mm}$ in diameter.

Remarks.-This specimen is laterally crushed. Shell is moderately involute, and has smooth flank without ornaments. It is very difficult to identify the generic name, but it may be placed in Stenopopanoceras by the characteristics of flank, volution and occurrence with Lenotropites cf. caurus of the Lower Anisian

Occurrence.-Horizon B3 of the Botneheia Formation in the Reinodden section.

Superfamily Cerataceae MoJsisovics, 1879

Family Acrochordiceratidae ARTHABER, 1911

Genus Paracrochordiceras SPATH, 1934

Type species.-Arcrochordiceras anodosum WELTER, 1915.

Paracrochordiceras sp.

Pl. 36, Figs. 6-7.

Material.-Two specimens, of which one (JM11559) is about $55 \mathrm{~mm}$ in diameter, the other (JM1560) $43 \mathrm{~mm}$, but they were laterally compressed.

Descriptive remarks. - The present specimens are moderate in size. The shell is evolute, with an umbilicus of $36 \%$ ratio to diameter of whorl. Whorl increases its height gradually, and has radial ribs on flanks, closing on ventral part. Ribs are not developed in inner whorl, and has irregular interval. Suture is not preserved.

\section{Explanation of Plate 36}

Figs. 1a-b and 3-5. Grambergia ? sp. B ........................ 237

Figs. 1a, 1b (JM11554), 3 (JM11555) and 4 (JM11556) $\times 1$ : Figs. 5 (JM11557) $\times 1.5$. Horizon: $\mathrm{B} 1$

Fig. 2. Leiophyllites ? sp. ..................................... 239 (JM11558) $\times 1.5$. Horizon: B1

Figs. 6 and 7. Paracrochordiceras sp. ....................... 227 (JM11559, JM11560) $\times 1.5$. Horizon: B1

Figs. 8-11. Lenotropites cf. tardus McLEARN .................... 236 (JM11561-JM11564) $\times 1.5$. Horizon: B1

Fig. 12 Grambergia ovinus (MCLeARN) ........................ 236 $(J M 11565) \times 2$. Horizon: B1 
Paracrochordiceras is one of representative ceratitid ammonites and known from the Anisian of the world. Spitsbergen's species is similar to P. americunum reported from British Columbia and Nevada of North America in having evolute whorl and strong ribs which pass over venter, but the former has also some characters on ribs of Epacrochordiceras, so the exact specific name is not able to name till better preserved materials come to hand.

Occurrence.-The materials were collected from the Lower Member of Botneheia Formation in the Reinodden section. The stratigraphic horizon is B1 occurring with Leiophyllites? sp., Grambergia? sp., Grambergia ovinus (McLEARN) and Lenotropites cf. tardus MCLEARN.

Family Ceratitidae MoJsisovics, 1879

Genus Hollandites DIENER, 1905

Type species.-Ammonites voiti OPPEL, 1863

\section{Hollandites orientalus BYTSCHKov et KIPARISOVA}

Pl. 38, Figs. 1-2.

1968. Hollandites orientalus BYTSCHKov et KIPARISOva; New species of ancient plants and invertebrates, USSR. p. 304.

1976. Hollandites orientalus BYTSChkov et KIPARISOva; BYTSchkov et al,; Atlas of Triassic fauna and flora of northeast USSR, p. 112, pl. 19, fig. 7, fig. 12-b.

Material.-Two incomplete specimens (JM11580 and JM11581), from the Botneheia Formation in the Reinodden section. In each of them about a half of the outer whorl encircling the umbilical part is preserved and its diameter is nearly $90 \mathrm{~mm}$ in a restored outline.

Descriptive remarks.-In each of those specimens about a half of the outer whorl encircling the umbilical part is preserved. The Shell is discoidal, involute, with rather narrow umbilicus and has broad and irregular ribs on side. The ribs appear at mid-flank and increase its width toward ventrolateral area, where they seem to be bullate. The interspaces in between broaden outward. The venter is rounded. No suture is preserved.

Some species of Hollandites have been known from northern parts of Spitsbergen by Frebold (1929b). The present specimens are easily identified to Hollandites orientalus reported from the Middle Triassic of the Taymyr Peninsula and Kolyma River of Siberia by BYTSCHCOV et KIPARISOVA (1968) and BYTSCHKov et al. (1976) in having the same characters of volution and ribbing.

Occurrence.-The described specimens occurred at the horizon B4, Middle Member of the Botneheia Formation at Reinodden section, and were associated with Hollandites sp. A, Anagymnotoceras cf. wrighti (MCLEARN) and Czekanowskites cf. hayesi (MCLEARN).

\section{Hollandites cf. pelletieri (MCLEARN)}

Pl. 39, Figs. 8-11.

Compare.-

1969. Hollandites pelletieri MCLeARN : Geol. Surv. Canada, Bull.170, p. 13-15, pl. 2, figs. 3-7; fig. 2.

1969. Hollandites cf. pelletieri MCLeARN; MCLeArN : ibid., p. 15, pl. 2, figs. 2a, b. 
1982. Hollandites cf. pelletieri MCLeArN; KorChInSKaYA: Expl. Meso. Str. Sch. Svalbard, pl. 20, fig. 6.

Material.-Four specimens (JM11596-JM11599).

Descriptive remarks. - The shell is moderate in size. The whorl expands slowly in early growth-stages, but rather rapidly later. The radial ribs are coarse in immature stages, slender later, and finally fading out. They end at the rounded ventrolateral shoulder and do not extend further on the venter.

The present specimens are somewhat similar to Hollandites cf. pelletieri reported by MCLEARN from the Toad Formation in British Columbia, Canada with respect to the characters of whorl volution and ribs. H. cf. pelletieri from the Torell point of Nordaustlandet (North-East Land) was illustrated by KoRCHINSKAYA, which has more involute whorl and broader, stouter ribs than the Spitsbergen's specimens.

Occurrence.-The present species occurs at the horizon ATr6 of the Anisian Botneheia Formation together with Anagymnotoceras cf. varium (MCLEARN).

\section{Hollandites sp. A}

P1. 38, Fig. 8.

Material.-A fragmentary whorl (JM11587).

Descriptive remarks. - The specimen is only an outer part of whorl, whose original shell is presumably about $90 \mathrm{~mm}$ in diameter, considerably discoidal and involute. The ribs are rectiradiate, slender on the inner part of the flank and spreading outward to the ventrolateral shoulder. The venter is rounded and smooth.

FREBOLD (1929b) reported some species of Hollandites from North Spitsbergen, of which Ceratites (Hollandites) cf. organi SмIтH and $C$. (H. ?) spp. are very similar to this specimen in having the characteristic ribs. $C$. (H.) organi was originally described by SMITH (1914) from Humboldt Range, Nevada. SILBERLING and NICHOLS (1982) revised this species to a synonym of Frechites occidentalis (SMITH, 1914). The latter of which has distinctly sinuous ribs which are projected on the ventrolateral area.

This specimen is associated with $H$. cf. orientalus, but it is discriminated from the latter in having stouter ribs.

Occurrence.-From the horizon B4 of Reinodden, the Anisian Botneheia Formation.

Hollandites sp. B

Pl. 39, Figs. 12-17.

Material.-Six replicated rubbers (JM11600-JM11605) which were taken from the original external moulds at hand.

Descriptive remarks.-The present specimens are all poorly preserved. The shells are small, about $40 \mathrm{~mm}$ in diameter in the largest one, moderately evolute in young stages, becoming involute in later stage. The ribs are rectiradiate, stout, and intercalatory. The present specimens are very similar to the specimens described as Ceratites (Gymnotoceras?) ex. aff. hersheyi SMITH and Ceratites sp. by FrEBold (1929b, pl. 3, figs. 7-9) from Festungprofil, Isfjorden, Spitsbergen. 
The holotype, Ceratites (G.) hersheyi from Nevada has nodes on the flank and a keel on the venter, and should be assigned to Frechites occidentalis of the uppermost Anisian (Silberling and Nichols, 1982). The specimens from Spitsbergen, including FREBOLD's and ours may belong to the genus Hollandites on the basis of present information.

Occurrence.-Horizon ATr7, middle of Botneheia Formation in the Ahlstrandodden section.

\section{Hollandites sp. C \\ Pl. 40, Fig. 4.}

Material.-A piece of fragmentary part of outer whorl (JM11610).

Descriptive remarks.-An outer whorl of evolute shell is estimated to be slightly over $35 \mathrm{~mm}$ in diameter. The specimen has rectiradiate or rursiradiate and considerably strong ribs on the flank. The present species is distinguished from the other species of Hollandites described above in having stouter ribs.

Occurrence.-Horizon ATr9 of the Botneheia Formation in Ahlstrandodden section.

Genus Anagymnotoceras McLEARN, 1966

[=Anacrochordiceras WANG et $\mathrm{HE}, 1976]$

Type species.-Gymnotoceras varium MCLEARN, 1948.

Anagymnotoceras cf. varium (MCLEARN)

Pl. 39, Figs. 1-7.

Compare.-

1948. Gymnotoceras varium MCLEARN : Geol. Surv. Can., Paper, 46-1, p. 33; Supplement, p. 2, pl. 11, figs. 5-6.

1960. Anagymnotoceras varium (McLearn) ; MCLeARN : Can. Field-Nat., 74, p. 53.

1966. Anagymnotoceras varium (McLearn) ; McLearn: Geol. Surv. Can., Paper, $66-56$, p. 1-2, pl. 1, fig. 11-13.

1969. Anagymnotoceras varium (MCLeARN); MCLEARN : Geol. Surv. Can., Bull., p. 18-19, pl. 3, figs. $7 \mathrm{a}-\mathrm{c}$; fig. 6 .

1982. Anagymnotoceras cf. varium (MCLEARN); Korchinskaya: Expl. Meso. Strat. Sch. Svalbard, p. 54-55, pl. 19, fig. 10; pl. 20, figs. 8, 10; fig. r.

Material.-Seven fragmentary specimens (JM11589-JM11595), of which the largest one (Fig. 1) is slightly more than $80 \mathrm{~mm}$ in diameter. They are secondarily compressed and shown on one side.

\section{Explanation of Plate 37}

Fig. 1. Grambergia ? sp. A ............................... 237 (JM11566) $\times 1$. Horizon: B3

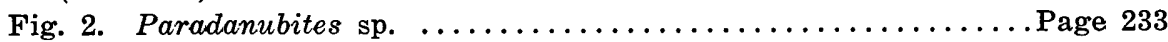
$(\mathrm{JM11567)} \times 1$. Horizon: B3

Figs. 3-14. Lenotropites cf. caurus (MCLEARN) ..................... 235 Figs. 3-13 (JM11568-JM11578) ; Fig. 14 (JM11618) $\times 1$. Horizon: B3

Fig. 15 Stenopopanoceras ? sp. .............................. 227 $(\mathrm{JM} 11579) \times 1$. Horizon: B3 

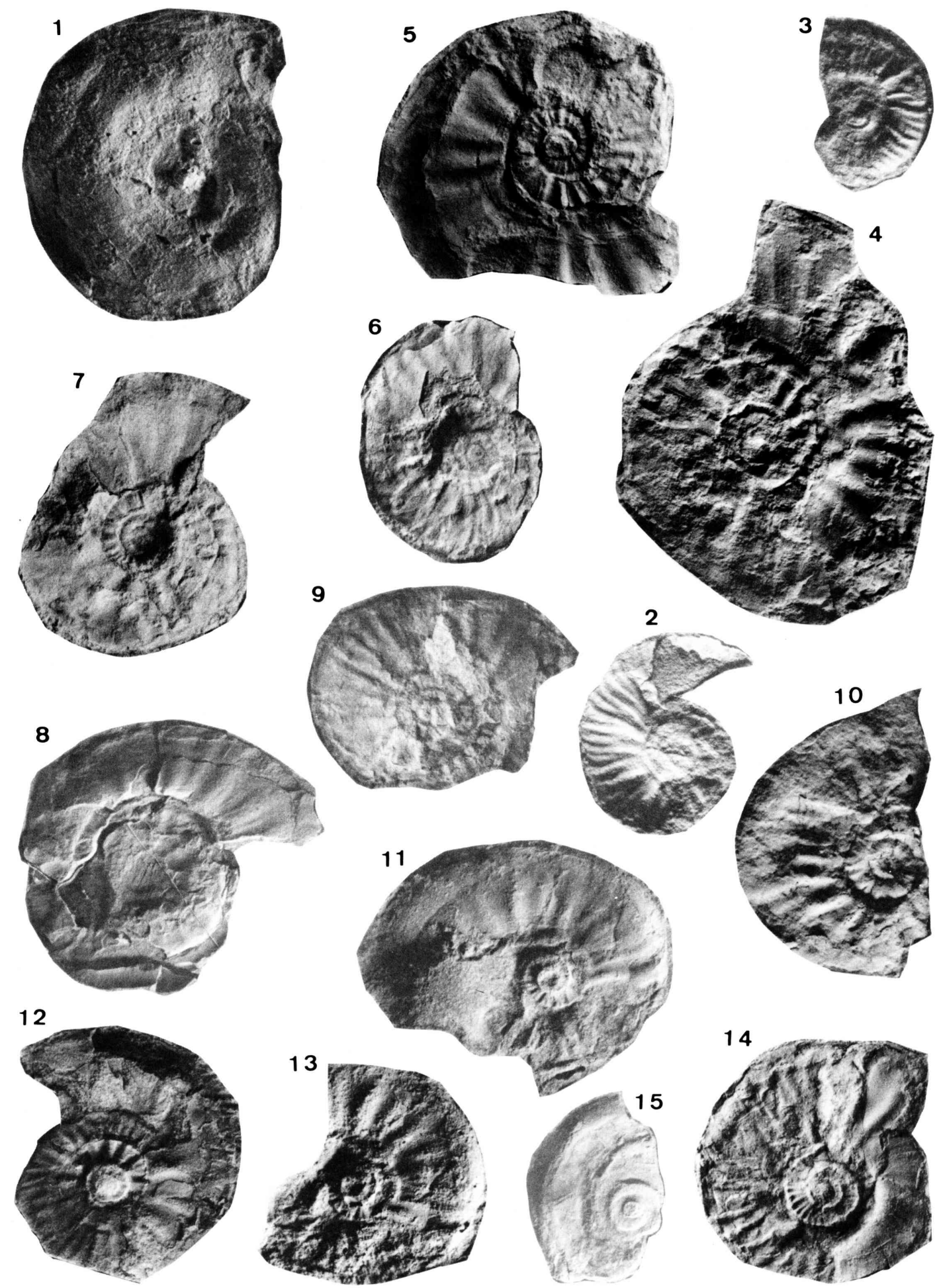

T. Ishibashi \& K. NAKAzawa: Triassic Ammonites from Spitsbergen 

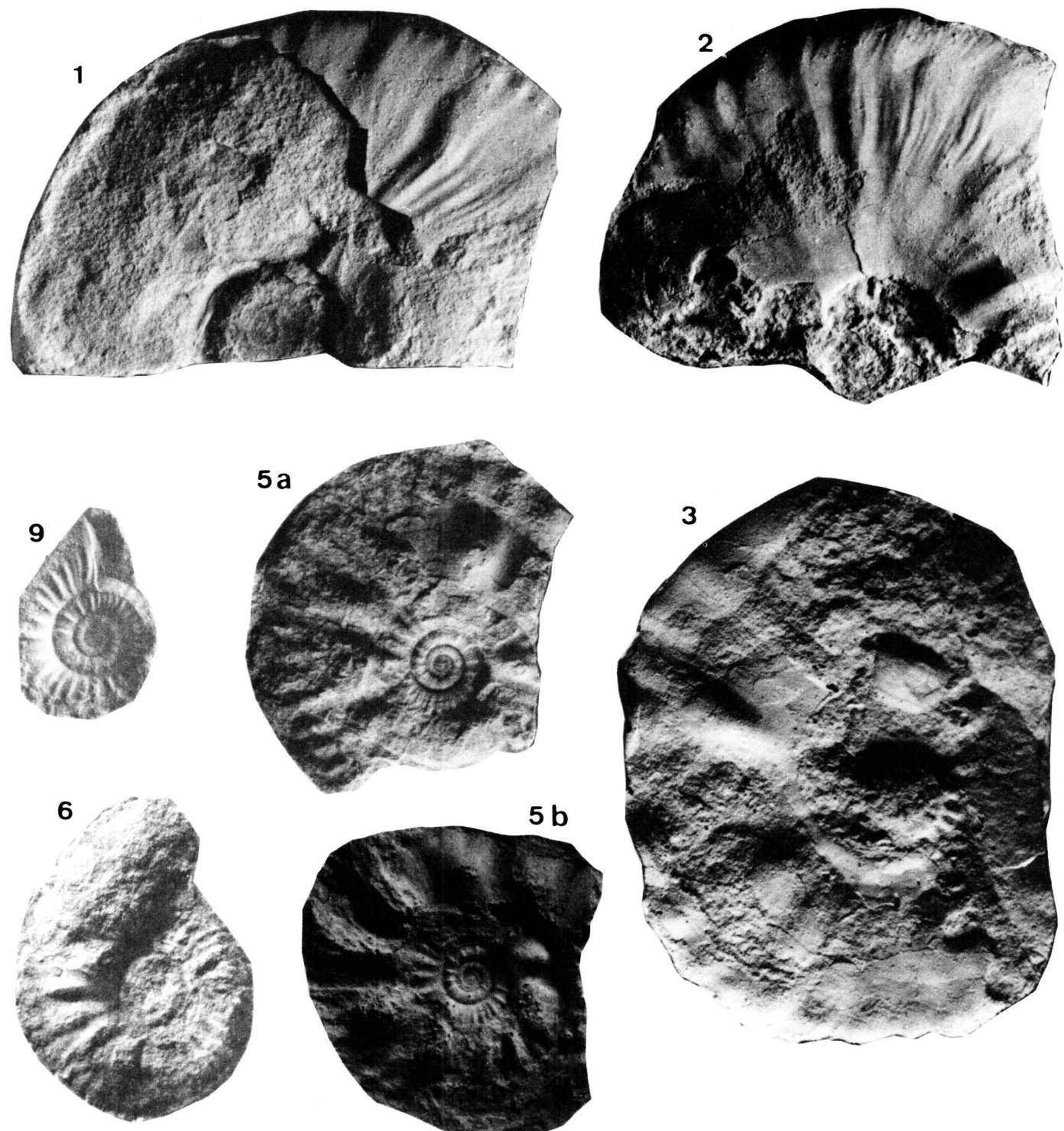

$5 b$
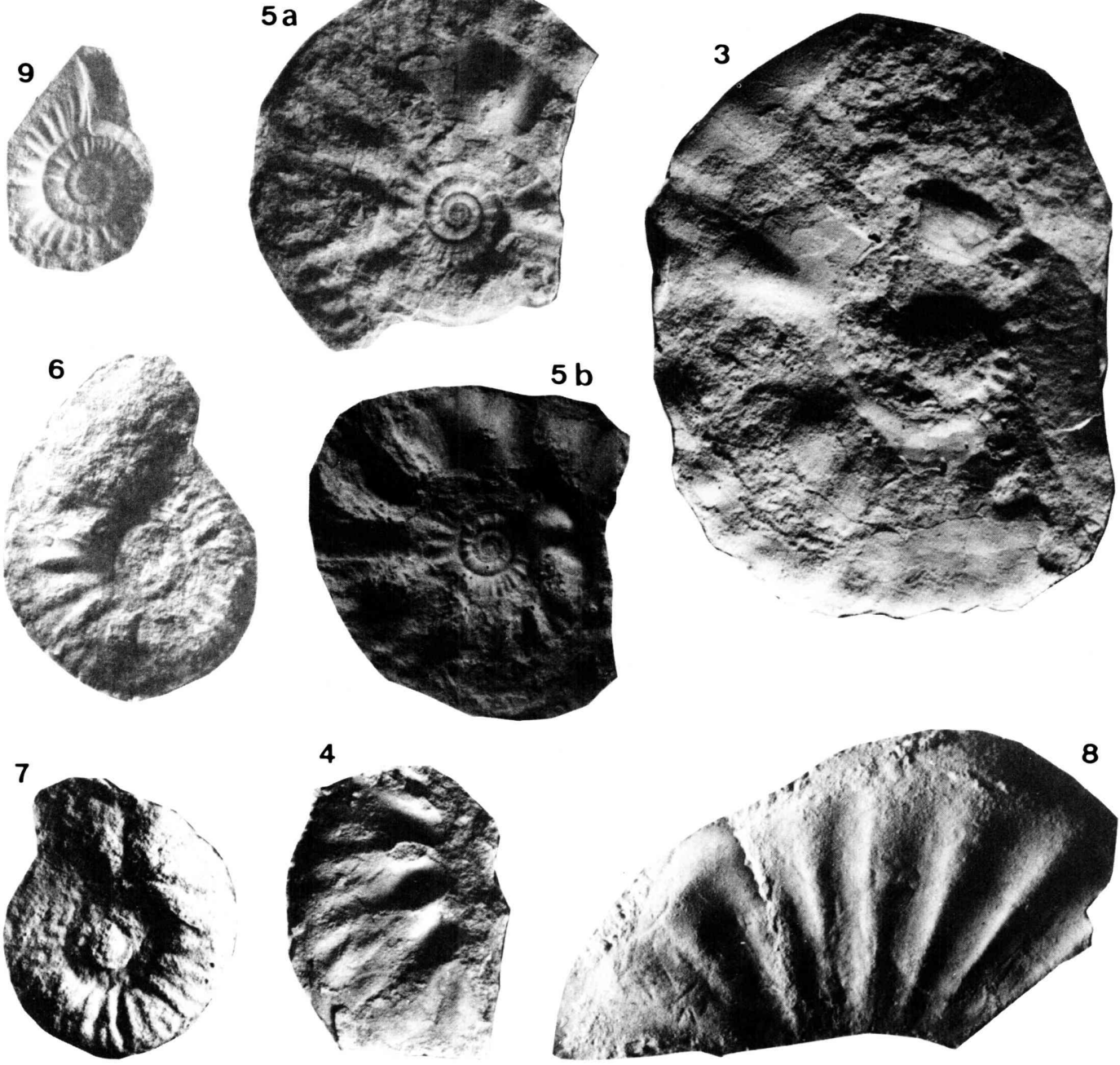

T. Ishibashi \& K. NAKAZAwa: Triassic Ammonites from Spitsbergen 
Descriptive remarks.--The whorl is rather evolute in early stage, but increases its height later and the outer whorl is moderately involute. Ribs are distant and rectiradiate. In the inner whorl they branch from the blunt bullae near the umbilical shoulder. In the outer whorl they change to distant long bullae on the flank, extending from umbilical edge to the ventrolateral shoulder. The venter is rounded.

The holotype of Anagymnotoceras varium was originally reported under the genus Gymnotoceras by McLEARN (1948) from British Columbia, Canada, but later the genus was revised to Anagymnotoceras by himself (1960). A further description in detail was given by TOZER (in MCLEARN, 1969). The present specimens are almost certainly identified with the holotype of Canada. KorCHINSKAYA (1982) reported $A$. cf. varium from the Torell point of North-East Land of Svalbard. One of her specimens (pl. 19, fig. 9) is very similar to the present one (Pl. 39, Fig. 1) in the characters of ribs and bullae.

Occurrence.-Horizon ATr6 of the Botneheia Formation in Ahlstrandodden section, where Hollandites cf. pelletieri MCLEARN is associated.

\section{Anagymnotoceras cf. wrighti (MCLEARN)}

Pl. 38, Figs. 3-5.

Compare.-

1948. Gymnotoceras wrighti McLearn: Geol. Surv. Can., Paper 46-1, p. 4, pl. 5, fig. 4; Suppl., p. 32, pl. 5, fig. 4.

1966. Anagymnotoceras wrighti (MCLEARN); MCLEARN : ibid., Paper 66-56, pl. 1, figs. 1-2.

1969. Anagymnotoceras wrighti (MCLEARN) ; MCLEARN : ibid., Bull. 170, p. 22-23, pl. 3, figs. 1a-b; fig. 8.

1982. Anagymnotoceras cf. wrighti (MCLEARN); KoRCHINSKAYA: Expl. Meso. Strat. Sch., Svalbard, p. 56, pl. 19, fig. 8; pl. 20, fig. 3; fig. 3b.

Material.-Three specimens (JM11581-JM11583) and a rubber mould taken from the external mould (JM11583).

Descriptive remarks. - The inner whorls are moderately evolute, but the outer whorl increases rapidly its height. The ribs are slender and rectiradiate on the flank of the inner whorls, whereas on that of the outer whorl they are stout and bi- or tri-partite from the thick bullae or nodes around the umbilical edge. The ventrolateral shoulder is rounded. The umbilicus is narrow, for instance about 16 percent of diameter in JM11583.

A. wrighti was reported by McLearn from the Toad Formation, British

\section{Explanation of Plate 38}

Figs. 1 and 2. Hollandites orientallus Bytschkov et Kiparisova ....Page 228 $(J M 11580$, JM11581) $\times 1$. Horizon: B4

Figs. 3-5. Anagymnotoceras cf. wrighti (McLeARN) ............... 231 (JM11581-JM11583) $\times 1$. Horizon: B4

Figs. 6, 7 and 9. Czekanowskites cf. hayesi (MCLEARN) ............ 233 Figs. 6, 7 (JM11584-JM11585) $\times 1$; Fig. $9(\mathrm{JM} 11586) \quad \times 1.5$. Horizon: B4

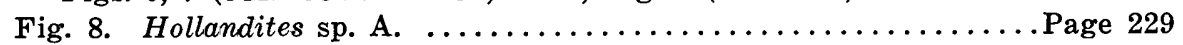
$(\mathrm{JM} 11587) \times 1$. Horizon: B4 
Columbia, Canada together with some other species of Anagymnotoceras. The present specimens have the same ornaments as those of MCLEARN's and are probably conspicific with the holotype. One of $A$. cf. wrighti described by KoRChINSKAYA (1982, pl. 19, fig. 8) from Sassendalen of Spitsbergen closely resembles one of ours (Pl. 38, Fig. 4). However, because our material consists of fragmentary specimens, we will call them $A$. cf. wrighti.

Occurrence.-Horizon B4 of the Botneheia Formation in the Reinodden section, where this species coexists with Hollandites orientalus, Hollandites sp. A, Czekanowskites cf. hayesi.

\section{Anagymnotoceras sp. \\ PI. 39, Fig. 19.}

Material.--Only one fragmentary specimen (JM11606) and its rubber mould.

Descriptive remarks. - This single specimen is roughly half a whorl of about $60 \mathrm{~mm}$ in diameter. The ornaments of inner whorls are not shown. The outer whorl has bullae around the umbilical margin, from which tripartite ribs run on the flank.

This specimen is somewhat similar to a specimen (Pl. 39, Fig. 4) of Anagymnotoceras cf. varium from Spitsbergen described above, but the former has clearer bullae and its ribs are curved rather than rectiradiate. However, because of poor preservation no specific name is given here.

Occurrence.-Horizon ATr7, the Botneheia Formation in the Ahlstrandodden section. This specimen is associated with Hollandites sp. B.

Genus Gymnotoceras HYATT, 1877

Type species.-Ammonites blakei GABB, 1864.

\section{Gymnotoceras todtmannae FREBOLD \\ P1. 40, Figs. 1-3.}

1929a. Gymnotoceras todtmannae FrEBOLD: Abh. Natuw., Hamburg, 22, 302, pl. 1, fig. 6.

1929b. Ceratites (Gymnotoceras?) sp. indet. ex. aff. Gymnotoceras hersheyi SMITH; FREBold: Skr. Svalb. og Ishavet, 26, p. 27, pl. 3, figs. 7-9.

1982. Gymnotoceras todtmannae FrEBOLD; KoRCHINSKAYA: Expl. Meso. Strat. Sch. Svalbard, p. 52-53, pl. 19, figs. 1-5; fig. 3a.

Material.-Three incomplete specimens (JM11607-JM11609).

Descriptive remarks.-Shell is small, $25 \mathrm{~mm}$ in the maximum diameter, consisting of evolute whorls which have slender rectiradiate or slightly prosiradiate ribs. Ribs are distant in early whorls, becoming denser in outer whorl, which has rounded and smooth ventral part.

This species has a small shell, which is only known from Svalbard. Ceratites (Gymnotoceras) hersheyi described by SMITH (1914) from Nevada was revised to Frechites nevadanus (MoJsisovics) by SILBERLING and Nichols (1982), but the specimens of $C$. (G. ?) ex. aff. hersheyi SMITH illustrated by FREBoLD are conspecific with the present species and should be referred to Gymnotoceras todtmannae. Even though the preservation of the present specimens leaves much to be desired, they are morphologically idntified to this species. 
Occurrence.-Horizon ATr9 of the Botneheia Formation in the Ahlstrandodden section, West Spitsbergen.

Superfamily Pinacocerataceae MoJsisovics, 1879

Family Ptychitidae MoJsisovics, 1882

Genus Ptychites MoJsisovics, 1875

[=?Ptychosphaerites SPATH, 1896; Sphaerites ARTHABER, 1896]

Type species.-Ammonites rugifer OPPEL, 1865.

Ptychites sp.

Pl. 40, Figs. 10 and 12a-b.

Material.-Two fragmentary specimens, JM11616 (Fig. 10) and JM11617 (Fig. 12).

Descriptive remarks.- Shell is involute with distant radial folds which fade at the ventrolateral shoulder. Venter is rounded. JM11617 (Fig. 12) consists of one fourth of globosal whorl showing a part of suture line, which is ammonitic and digitate, having numerous lobes and saddles with accessory lobes.

The present specimens are poorly preserved, but on the ground of the remaining features of the conch, they are assigned to the genus Ptychites. They are somewhat similar to KORCHINSKAYA's specimens from the Dickson Land of Isfjorden illustrated under Ptychites trochlaeformis (LINDSTROEM), a well known species from the Svalbard Anisian formation, although they are too incomplete for the specific identification.

Occurrence.-Horizon B5, the Middle Member of Botneheia Formation in the Reinodden section.

Superfamily Danubitaceae SPATH, 1951

Family Danubitidae Spath, 1951

Genus Paradanubites SheVYrev, 1968

Type species.—Danubites kansa DIENER, 1895.

Paradanubites sp.

P1. 37, Fig. 2.

Material.-A small specimen (JM11567), about $27 \mathrm{~mm}$ in diameter.

Descriptive remarks.- Shell is moderately evolute with radial ribs which are often bifurcated or intercalated. Ventral and umbilical shoulders are subrounded. Suture is not preserved. On the basis of its characteristic ornaments it is assigned to the genus Paradunubites.

Occurrence.-Horizon B2 of the Lower Member of the Botneheia Formation in the Reinodden section.

Genus Czekanowskites DIENER, 1916

[=Epiczekanowskites PoPov, 1961; ?Subarctoceras Popov, 1961 (nom. nud.)]

Type species.-Ceratites decipiens MoJsisovics, 1886.

Czekanowskites cf. hayesi (MCLEARN)

Pl. 38, Figs. 6, 7 and 9. 
Compare.-

1946a. Ceratites ? hayesi MCLeARn: Geol. Surv. Can., Paper 46-1, Appendix II, p. 2, pl. 1, fig. 2 .

1946a. Ceratites? hayesi var. angulatus McLeARN; MCLeARN: ibid., p. 2.

1946a. Ceratites ? hayesi var. piguis MCLEARN; MCLEARN: ibid., p. 2.

1969. Czekanowskites hayesi (MCLearN); MCLEARN : Geol. Surv. Can. Bull., 170, p. 43-44, pl. 1, figs. 4-8; figure 22 .

1976. Czekanowskites hayesi (MCLEARN) ; BYTSCHKov: Atlas of Triassic fauna and flora of northeast USSR, p. 100, pl. 17, figs. 3, 4.

1982. Czekanowskites hayesi (MCLEARN); KoRCHINSKAYA: Expl. Meso. Strat. Sch. Svalbard, p. 61 , pl. 20, figs. $1,2$.

1982. Czekanowskites hayesi (MCLeARN); Silberling and Nichols: U. S. Geol. Surv., Prof. Pap., 1207, p. 43, pl. 19, fig. 16-19.

Material.-Three specimens, JM11584, JM11585 (Figs. 6-7), and JM11586 (Fig. 9), with diameters of 45,38 and $20 \mathrm{~mm}$ respectively.

Descriptive remarks.--Shell is small, laterally compressed and rather evolute. Immature shell has slender, rectiradiate ribs. Outer whorl rapidly expands and has bullae around the umbilical margin, and the ribs branched from the bullae are fading with growth. Suture line is not preserved.

The original paper in which the holotype and other variations were described is not accessible but their photographs were re-illustrated by MCLEARN (1969). This species was reported from Nevada (SILBERLING and Nichols, 1982) and Spitsbergen (KoRCHINSKaYA, 1982). The projected ribs on the ventrolateral shoulder are not recognized in our specimens of poor preservation. KoRCHINSKAYA's specimens were collected from the north coast of Van Keulenfjorden area. Those Spitsbergen specimens somewhat resemble ours.

Occurrence.-Horizon B4 of the Botneheia Formation in the Reinodden section.

Family Longobarditidae SPATH, 1951

[= Neodalmatidae (sic) ARCHIPOv, 1974]

Subfamily Groenlanditinae Assereto, 1966

Genus Lenotropites PoPov, 1961

[= ?Koptoceras SPATH, 1951 (nom. dub.)]

Type species.-Lenotropites solitarius Popov, 1961.

\section{Explanation of Plate 39}

Figs. 1-7. Anagymnotoceras cf. varium (McLEARN) ............... Page 230 $(J M 11589-J M 11595) \times 1$. Horizon: ATr6

Figs. 8-11. Hollandites ef. pelletieri MCLearn .................... 228

Figs. 8 (JM11596) and 11 (JM11599) $\times 1$; Figs. 9 (JM11597) and 10 (JM11598) $\times 1.5$. Horizon: ATr6

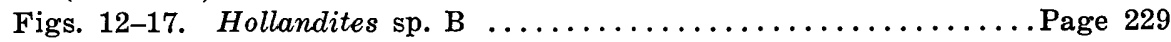
Fig. $12($ JM11600) $\times 1.5:$ Figs. $13-17($ JM11601-JM11605) $\times 1$. Horizon: ATr7

Figs. 18. Nathorstites ? sp. A ................................. 238 (JM11619) $\times 1.5$. Horizon: $10 \mathrm{~b}$

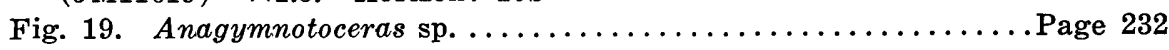
$(\mathrm{JM} 11606) \times 1$. Horizon: ATr7 


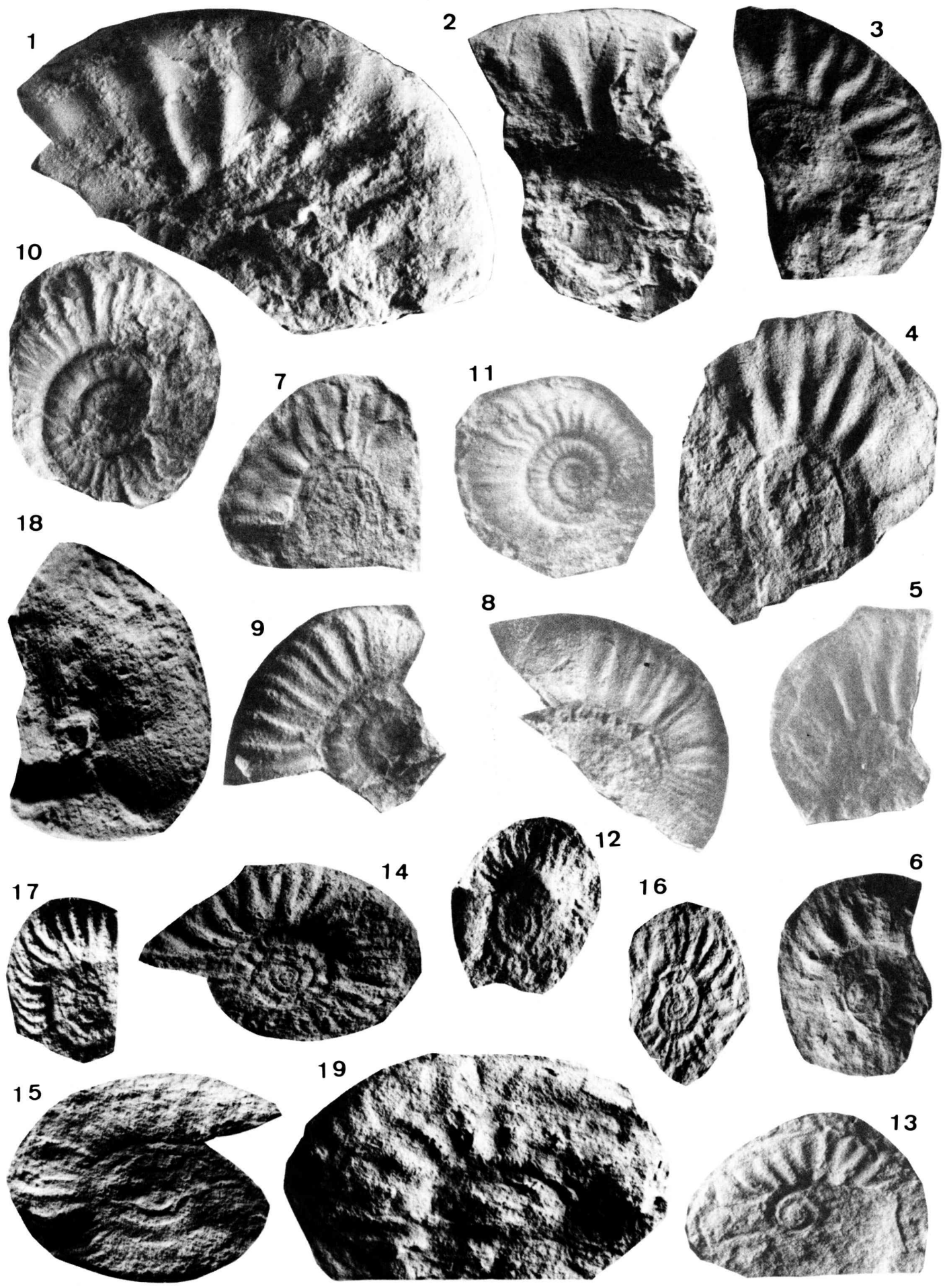

T. Ishibashi \& K. NAKAZAwa: Triassic Ammonites from Spitsbergen 

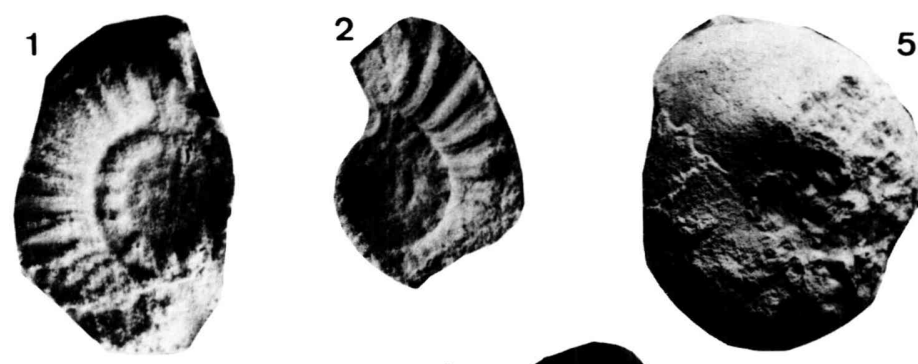

\section{5}
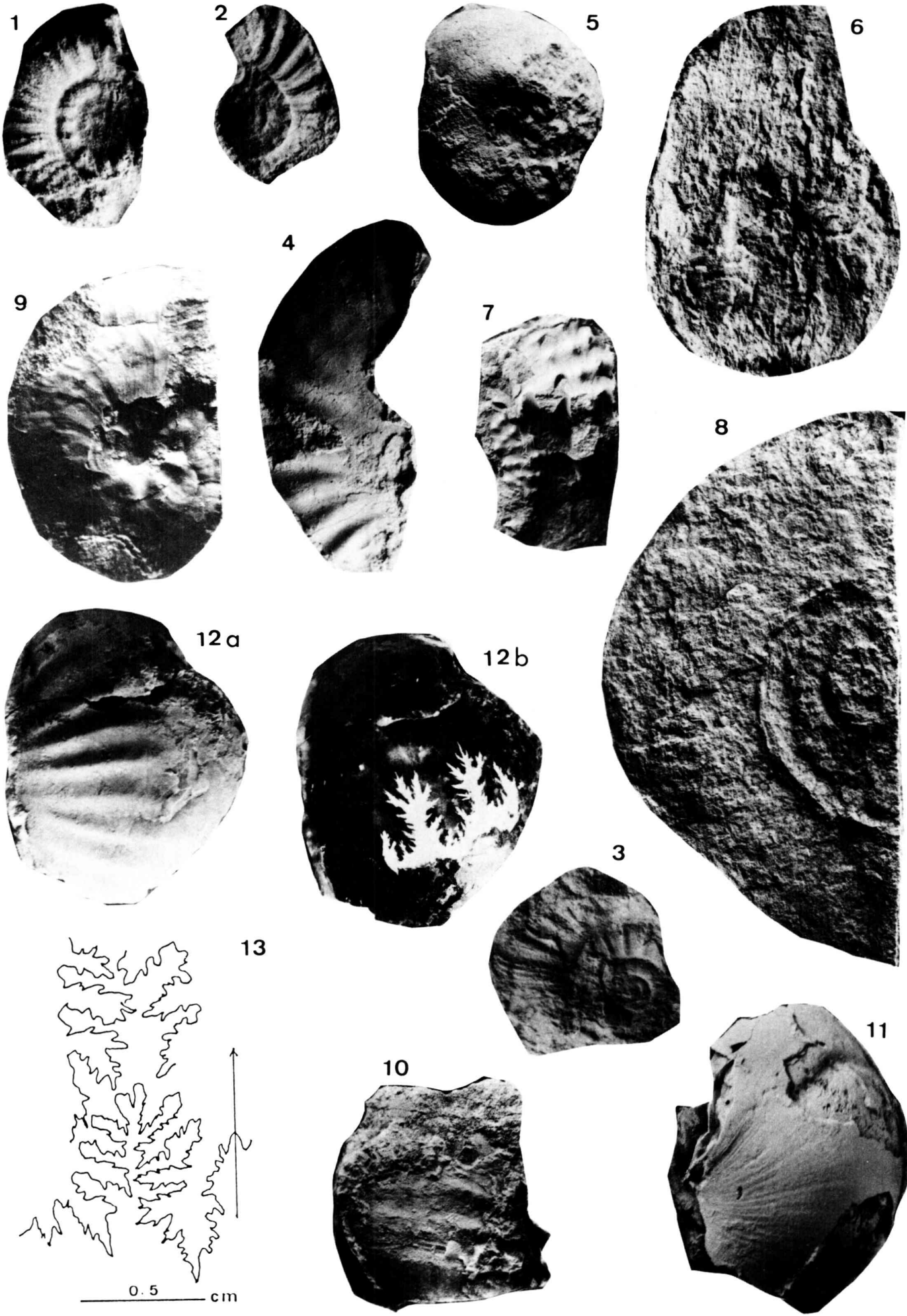

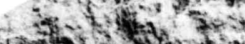

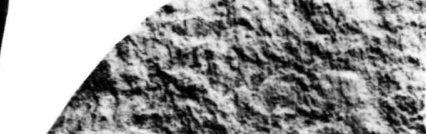

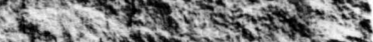

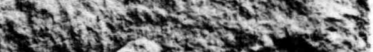

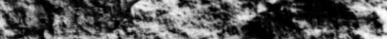

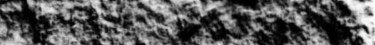

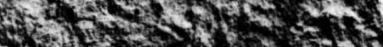

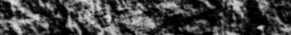

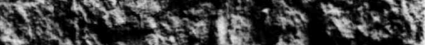

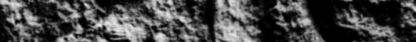

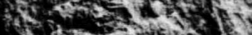

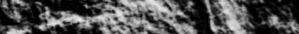
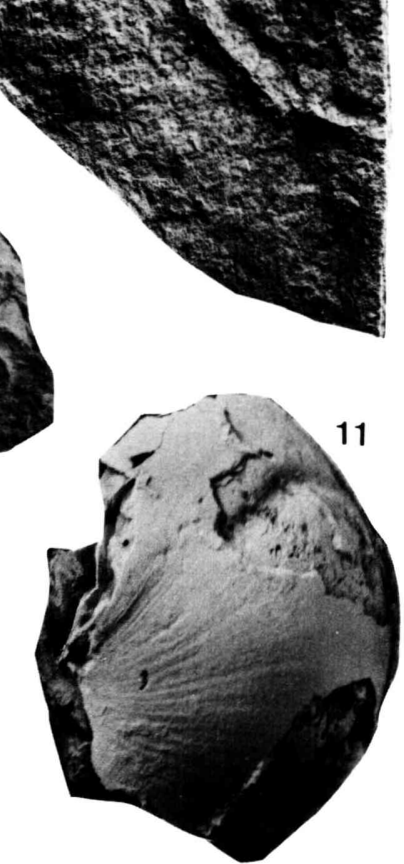

T. Ishibashi \& K. Nakazawa: Triassic Ammonites from Spitsbergen 


\section{Lenotropites cf. caurus (McLEARN) \\ Pl. 37, Figs. 3-14.}

\section{Compare.-}

1948. 'Hungarites' caurus McLearn: Geol. Surv. Can., Paper, 46-1, Suppl., p. 1, pl. 11, figs. 1, 2.

1948. 'Hungarites' boreas MCLeARN : ibid., p. 2, pl. 11, figs. 3, 4.

1948. 'Hungarites' dawsoni McLeARN : ibid., p. 2, pl. 10, figs. 8, 9.

1969. Lenotropites caurus (McLearN); McLearn: Geol. Surv. Can., Bull., 170, p. $41-43$, pl. 8, figs. $4-7$; fig. 21 .

1982. Lenotropites caurus (McLEARN); Korchinskaya: Expl. Meso. Strat. Sch. Svalbard, p. 63, pl. 16, fig. 10; fig. 4e.

1982. Lenotropites caurus (MCLEARN) ; SilbERLING and Nichols: U. S. Geol. Surv., Prof. Pap., 1207, p. 46, pl. 29, figs. 14-30; text-fig. 30 .

Material.-Eleven specimens (Figs. 3-13, JM11568-JM11578; Fig. 14, JM11618). They are from 70 to $40 \mathrm{~mm}$ in diameter.

Descriptive remarks.- Shell is moderate in size. The whorl is rather evolute and has slender, straight ribs in early stage, but increases its height in the last stage. Ribs are stout and straight on the inner part of flank and fade out at the ventrolateral shoulder. Ribs disappear entirely in some mature shells. The ventral part and suture line are not observable in these specimens.

The holotype collected from the Toad Formation, British Columbia, Canada was illustrated in 1948 and described in detail in 1969 by McLEARN. This species illustrated by SILBERLING and NichOLS are well preserved and designated as a representative species of the Lower Anisian in North America (TozER, 1967; SILBERING and TozER, 1968). Korchinskaya also described this and allied species from the islands situated in the eastern part of Spitsbergen. The present specimens are remarkably similar to the specimens of North America in general features.

\section{Explanation of Plate 40}

Figs. 1-3. Gymnotoceras todtmannae FreboLd ........................ 232 (JM11607-JM11609) $\times 1.5$. Horizon: ATr9

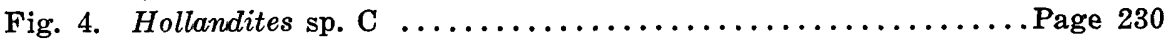
(JM11610) $\times 1.5$. Horizon: ATr9

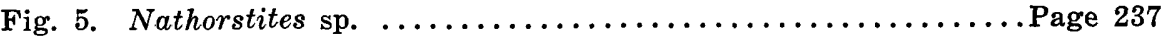

(JM11611) $\times 1.5$. Horizon: ATr10

Fig. 6. ammonoid gen. et sp. indet. $(\mathrm{JM} 11612) \times 1$. Horizon: ATr10

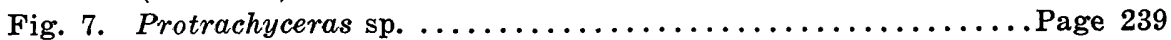
(JM11613) $\times 1.5$. Horizon: RTr74

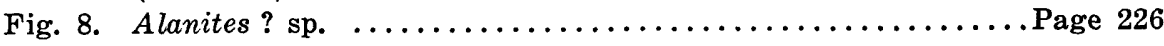

(JM11614) $\times 1$. Horizon: RTr74

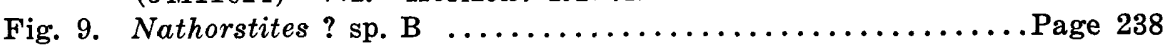
$(\mathrm{JM11615)} \times 1$. Horizon: KT-1

Figs. 10 and 12a-b. Ptychites sp. ............................. 233 Fig. 10 (JM11616), Fig. 12 (JM11617) $\times 1$. Horizon: B5

Figs. 11 and 13. Proarcestes sp. $\ldots \ldots \ldots \ldots \ldots \ldots \ldots \ldots \ldots \ldots$. Page 238

Fig. 11. (JM11617) $\times 1.5$. Horizon: B5

Fig. 13. suture-line. 
Occurrence.-Horizon B3 of the Lower Member of Botneheia Formation in the Reinodden section, Wedel Jarlsberg Land, Spitsbergen.

\section{Lenotropites cf. tardus MCLEARN \\ Pl. 36, Figs. 8-11.}

Compare.-

1969. Lenotropites tardus McLeARN: Geol. Surv. Can., Bull., 170, p. 39, pl. 8, figs. 1-3; figure 19.

1982. Lenotropites tardus McLearn; Korchinskaya: Expl. Meso. Strat. Sch. Svalbard, p. 64, pl. 16, fig. 2; pl. 18, figs. 1-3; fig. 4.

Material.-Four specimens (JM11561-JM11564).

Descriptive remarks. - The shell is small in size, $20 \mathrm{~mm}$ in the maximum diameter (JM11561) and involute. Ribs are coarse up to the middle growth stage. Later they fade out on outer part of the whorl and form bullae at the umbilical margin. Because of lateral crushing, suture line and a ventral keel cannot be observed in our specimens.

The present specimens are remarkably similar to the specimens assigned to Lenotropites tardus by KoRCHINSKAYA (1982) from several localities in Svalbard in the general features. The holotype described by McLEARN from Canada has more involute shell than the Spitsbergen specimens.

Occurrence.-Horizon B3 of the Botneheia Formation in the Reinodden section.

Subfamily Longobarditinae, SPATH, 1951

Genus Grambergia PoPov, 1961

Type species.-Grambergia taimyrensis PoPov, 1961.

Grambergia ovinus (MCLEARN)

Pl. 36, Fig. 12.

1948. 'Hungarites' ovinus McLeARN: Geol. Surv. Can., Paper, Suppl., p. 2, pl. 12, figs. 1-2.

1951. Longobardites ovinus (MCLeARN) ; MCLEARN : ibid., Suppl. to 46-1, p. 15.

1969. Grambergia ovinus (MCLEARN); MCLEARN : ibid., Bull., p. 37, pl. 7, figs. 1a-b; fig. 16.

1982. Grambergia ovinus (MCLEARN); KorChinskaya: Expl. Meso. Strat. Sch. Svalbard, p. 66, pl. 17, figs. 3-4; fig. 5a.

Material.-A single specimen (JM11565), showing sutures.

Descriptive remarks.- Shell is small, $25 \mathrm{~mm}$ in diameter, very involute, discoidal and laterally compressed. Flank is smooth without rib and tubercle. Umbilicus is very small having $2.7 \mathrm{~mm}$ in width occupying only $11 \%$ of shell diameter. Venter is acute. Suture line is ceratitic, having high saddle.

The holotype of this species is larger than our specimen, but in other features the latter is regarded as identical with the former. It is very much like the specimens described under the same species by KoRchINSKAYA (1982) from the Lower Anisian of the Edgeøya (Edge Is.) in Svalbard.

Occurrence.-Horizon B1 of the Lower Member of Botneheia Formation in the Reinodden section. 
Grambergia? sp. A

Pl. 37, Fig. 1.

Material.-A specimen of outer mould (JM11566) of $50 \mathrm{~mm}$ in diameter. The rubber cast made from it is here examined.

Remarks. -The shell is involute, discoidal, laterally compressed and smooth without ribs and tubercles on the flank. It looks like G. cf. nahwisi (McLEARN) described by KoRchinsKaYA (1982) from Wahlbergøya, but is too poorly preserved for the specific identification. We merely document the occurrence of this form.

Occurrence.-Horizon B3 of the Lower Member of Botneheia Formation in the Reinodden section.

Grambergia? sp. B

Pl. 36, Figs. 1a-b and 3-5.

Material.-Four specimens (Fig. 1, JM11554; Fig. 3, JM11555; Fig. 4, JM11556; Fig. 5, JM11557). One of which, Fig. 1, consists of external mould and cast. They are 24 to $65 \mathrm{~mm}$ in diameter.

Descriptive remarks.-Shells are involute and laterally compressed. The umbilicus seems to be narrow, although the outline of the next inner whorl is impressed. Almost no distinct ornament on the flank, but for very fine, gently flexiradiate lirae and grooves or constrictions.

It is difficult to refer these crushed specimens definitely to any genus, but outline is somewhat similar to that of some species of Grambergia, such as $G$. cf. nahwisi (KoRCHINSKAYA, 1982) and G. taimyrensis (PoPov, 1961). The fine constrictions of our specimens are similar to those of Longobardites nevadanus described by MCLEARN (1969) from the Caurus Zone of Lower Anisian in British Columbia, Canada. However, because of their poor preservation, more material is needed for the precise comparison.

Occurrence.-Horizon B1, the Lower Member of Botneheia Formation in the Reinodden section.

Superfamily Nathorstitaceae SPATH, 1951

Family Nathorstitidae SpATH, 1951

Genus Nathorstites BоEнM, 1903

[= ?Metasphingites PoPov, 1961]

Type species.-Popanoceras mcconnelli WHITEAVES, 1889.

Nathorstites sp.

Pl. 40, Fig. 5.

Material.-An incomplete specimen (JM11611) which shows the umbilical part.

Remarks.-Shell is globose and involute with narrow umbilicus. No ornament is on the flank, but for a raised mound around the umbilicus. These features somewhat resemble those of Nathorstites lindstroemi (WHITEAVES) from Kolyma illustrated by PoPOV. (1961). Several species of Nathorstites were reported from 
Svalbard by a number of authors, but this specimen cannot be precisely compared with any of them, because of its too poor preservation.

Occurrence.-Horizon ATr10 of the Botneheia Formation in the Ahlstrandodden section. The present specimen is associated with an indeterminable ammonoid.

Nathorstites? sp. A

Pl. 39, Fig. 18.

Material.-Several specimens were collected from the uppermost horizon of the Botneheia Formation, one of which (JM11619) is here illustrated and the largest shell is $30 \mathrm{~mm}$ in diameter.

Remarks.-Shell is involute, discoidal and laterally compressed. It is smooth, without rib and tubercle. These features are apparently similar to those of Nathorstites or Indigirites. Indigirites has narrowed whorl and acute venter. Therefore, it may be better to ascribe this species to Nathorstites, though with a query.

Occurrence.-Horizon B10b, the uppermost of the Botneheia Formation in the Reinodden section.

Nathorstites? sp. B

Pl. 40, Fig. 9.

Material.-A fragmentary specimen (JM11615).

Remarks.-Shell is involute, with a very narrow umbilicus, discoidal and $50 \mathrm{~mm}$ in diameter. It has slender rectiradiated constrictions. The inner whorl has tubercle-like elevations separated by furrows around the umbilical margin.

The present species is large for the genus. It is somewhat similar to Nathorstites gibbosus STOLLEY illustrated by KORCHINSKAYA from the Carnian Kapp Toscana Formation in the northern area of Edgeøya in having furrows around the umbilical margin. Other species belonging to this genus are smaller than this species and have smooth flank. It needs better preserved material to determine definitely its taxonomic position.

Occurrence.-Horizon KT 1 of the lowest Member of Kapp Toscana Formation in the Reinodden section.

Superfamily Arcestaceae MoJsisovics, 1875

Family Arcestidae MoJsisovics, 1875

Genus Proarcestes MoJsisovics, 1893

Type species.-Arcestes bramantei Mojsisvics, 1893.

Proarcestes sp.

Pl. 40, Figs. 11 and 13.

Material.-A fragmentary specimen (JM11617) consisting of about one third of whorl.

Descriptive remarks.-Shell is involute, globose, and estimated to be $40 \mathrm{~mm}$ or more in diameter. Whorl is broad, $40 \mathrm{~mm}$ in width, deeply embracing the inner one. Its surface is nearly smooth for numerous, radial lirae and a few 
oblique, constrictions crossing over the venteral part. The suture is partly exposed as illustrated on Pl. 40, Fig. 13.

Proarcestid ammonite has never been reported from Svalbard. The present species is similar to certain species of Nathorstites in having the same type of periodic constrictions, but the latter differs from the former primarily in having the suture of ceratitic pattern. However, aside from the incomplete preservation, the remaining features of the conch resemble those of Proarcestes.

Occurrence.-Horizon B5 of the Botneheia Formation in the Reinodden section.

Superfamily Trachycerataceae HAUG, 1894

Family Arpaditidae HYatT, 1900

Genus Protrachyceras MoJsisovics, 1893

Type species.-Trachyceras archelaus LAUBE, 1869

Protrachyceras sp.

Pl. 40, Fig. 7.

Material.-Ventrolateral part of a fragmentary whorl (JM11613).

Remarks.-The whorl shape is not known from this material. The conch has many tubercles on lateral and ventral parts. The rows of tubercles on side make low, radial ribs. Some trachyceratids are known from Svalbard, of which, Protrachyceras sp. illustrated by KoRchINSKAYA (1982) from the Ladinian of Spitsbergen is somewhat similar to the present specimen in having the pattern of tubercle features. However, it is necessary to get better preserved specimens from a definite stratigraphic position for the identification of the specific name.

Occurrence.-The horizon is not precisely known, because the specimen was obtained from a block near locality ATr7 in the Ahlstrandodden section.

Order Phylloceratida ARKelL, 1950

Superfamily Phyllocerataceae ZITTEL, 1884

Family Ussuritidae HYATT, 1900

[=Monophyllitidae Smith, 1913; Palaeophyllitidae PoPov, 1958]

Genus Leiophyllites DIENER, 1915

[= ?Mangyshlakites SHEVYREV, 1968]

Leiophyllites? sp.

Pl. 36, Fig. 2.

Material.-One specimen (JM11558), $37 \mathrm{~mm}$ in diameter.

Remarks.- Shell is evolute, laterally compressed and smooth on its surface. The suture is invisible. It can be placed in the ussuritid group on the basis of the whole features of the shell. The present species is somewhat similar to Ussurites spetsbergensis SPATH (1934), from the Lower Anisian, Botneheia Formation, Sassen Bay, Ice Fjord, but the latter has faint radial ribs on the outer whorl. The former is rather closely related to Leiophyllites sp. illustrated by KoRCHINSKAYA from Wilhelmøya, Svalbard, and may be referrable to Leiophyllites.

Occurrence.-Horizon B1, Lower Member of the Botneheia Formation in the Reinodden section. 


\section{References}

Buchan, S. H., Challinor, A., Harland, W. B. and Parker, J. R. (1965) : The Triassic stratigraphy of Svalbard. Norsk Polarinst. Skr., (135), 94 p.

Bytschkov, Yu. M. and Kiparisova, L. D. (1968): Some Middle Triassic ceratitids in North and Northeast Asia. New species of ancient plants and invertebrates, USSR. 299-308. (in Russian)

et al. (1976): Atlas of Triassic fauna and flora of Northeast USSR. $267 \mathrm{p}$. incl. 70 pls., (Nedra), Moscow. (in Russian)

Flood, B., NAGY, J. and Winsnes, T. S. (1971): The Triassic succession of Barentsøya and Hopen (Svalbard). Meddr. Norsk Polarinst., (100), 1-24.

Frebold, H. (1929a): Faunistisch-stratigraphische Untersuchungen über die Trias Spitsbergens und der Edge Insel. Abh. Naturw. Hamburg, 22, 297-312, pls. 1-2. (1929b): Untersuchungen über die Fauna, die Stratigraphie und Palaogeographie der Trias Spitsbergens. Skr. Svalb. og Ishavet, (26), 1-66, pls. 1-6.

Gazdzicki, A. and Trammer, J. (1977) : The sverdrupi Zone in the Lower Triassic of Svalbard. Acta Geol. Polonica, 27, (3), 349-356.

Hatleberg, E. W. and Clark, D. L. (1984): Lower Triassic conodonts and biofacies interpretations: Nepal and Svalbard. Geol. Palaeont., 18, 101-125.

KoRCHINSKAYA, M. V. (1982): Explanatory note on stratigraphic scheme of Mesozoic (Triassic) of Svalbard. "SEVMORGEOLOGIA", Regional Geology, 1-99, pls. 1-30, Leningrad. (in Russian)

(1986) : Biostratigraphy of Induan in Spitsbergen. Geology of sedimentary rocks in Spitsbergen. ibid., 77-93, pls. 1-7, Leningrad. (in Russian)

-, Klubov, B. A. and Pchelina, T. M. (1967) : In Sokolov, V. N. (ed.) : Stratigraphy of Spitsbergen. (in Russian) (English translation, The British Library, 1977)

—_ and Vavilov, M. N. (1987) : Early Induan ammonoids from Spitsbergen. In Zakharov, Yu. D. and ONoprienko, Yu. I. (eds.). Problems of the Permian and Triassic biostratigraphy of East USSR. Vladivostok: Far-Eastern Russian Scientific Centre, USSR Acad. Sci., 64-73, pls. 1-4. (in Russian with English abstract)

MørK, A., KNARUd, R. and Worsley, D. (1982): Depositional and diagenetic environments of the Triassic and Lower Jurassic succession of Svalbard. In EMBRY, A. F. and Balkwill, H. R. (eds.) : Arctic Geology and Geophysics. Canad. Soc. Petrol. Geol., Mem. 8, 371-398.

McLearn, F. H. (1946) : A Middle Triassic (Anisian) fauna in Halfway, Sikanni Chief and Testa Valleys, northeastern British Columbia 1-20 (Mimeographed); $A p$ pendix 1 . The Middle Triassic of Liard River, British Columbia, by KINDLE, E. D., 21-23 (Mimeographed); Appendix II, New Middle Triassic species from northeastern British Columbia, 1-2, pls. 1-3, figs. 1a-d, Geol. Surv. Canada, Paper 46-1. (1947): The Triassic Nathorstites Fauna in northeastern British Columbia. ibid., Paper 47-24, 27 p., appendix, 2 p., pls. 1-7.

(1948): A Middle Triassic (Anisian) fauna in Halfway, and Tetsa valleys, northeastern British Columbia (2nd ed.). ibid., Paper 46-1, 1-3, pls. 1-12.

(1951): The ammonoid family Hungaritidae, and the species Longobardites nevadanus in the Middle Triassic Series of northeastern British Columbia. ibid., Suppl. to Paper 46-1, 1-26.

(1960): Revision of some Anisian (Middle Triassic) ammonoids. Can. FieldNaturalist, 74, p. 53.

(1966): Anagymnotoceras, a new Middle Triassic (Anisian) ammonoid from northeastern British Columbia. Geol. Surv. Canada, Paper 66-56, 1-3, pl. 1.

(1969): Middle Triassic (Anisian) ammonoids from northeastern British Columbia and Ellesmere Island. Geol. Surv. Canada, Bull., 170, 1-90, pls. 1-8.

Nakazawa, K., NAKamura, K. and Kimura, G. (1987) : Discovery of Otoceras boreale Spath from West Spitsbergen. Proc. Japan Acad., 63, [B], (6), 171-174. 
- SuzukI, S., Kumon, F. and Winsnes, T. S. (1990): Scientific results of the Japanese Geological Expedition to Svalbard, 1986. In TATSUMI, T. (ed.), Scientific Reports of Japanese Expeditions to Svalbard, 1983-1988, Kyoikusha, Ltd., Tokyo. (in press)

Popov, Yu. N. (1961): Triassic ammonoids of north-east USSR. Trans. Res. Sci. Inst. Geol. Arctic, 79, Leningrad, 1-175, 25 pls. (in Russian)

Shevyrev, A. A. (1968): Triassic ammonoids of south USSR. Trudy Paleont. Inst., 119, 272 p., 21 pls. (in Russian)

Silberling, N. J. and Nichols, K. M. (1982): Middle Triassic molluscan fossils of biostratigraphic significance from the Humboldt Range, Northwestern Nevada. U.S. Geol. Surv., Prof. Pap., 1207, 1-77, pls. 4-38.

- and TozER, E. T. (1968): Biostratigraphic classification of the marine Triassic in North America. Geol. Soc. Amer., Spec. Paper, 110, 1-57.

Smith, J. P. (1914) : The Middle Triassic marine invertebrate faunas of North America. U.S. Geol. Surv., Prof. Pap., 83, 1-83, pls. 1-99.

Spath, L. F. (1921): On Ammonites from Spitsbergen. Geol. Mag., 297-305, and $347-356$.

(1934): The Ammonoidea of the Trias (I). Cat. Fossil Cephalopoda Brit. Mus. (Nat. Hist.), Pt. 4, 521 p., pls. 1-18, London.

SwEET, C. W. (1988) : A quantitative conodont biostratigraphy for the Lower Triassic. Senckenberg. Lethaea, 69, (3/4), 253-273.

Tozer, E. T. (1961) : Triassic stratigraphy and faunas of Queen Elizabeth Islands, Arctic Canada. Geol. Surv. Canada, Mem., 316, 1-116, $30 \mathrm{pls}$. (1962) : Illustrations of Canadian fossils, Triassic of western and Arctic Canada. Geol. Surv. Canada, Paper 62-19, 1-26, 12 pls.

(1967): A standard for Triassic Time. Geol. Surv. Canada, Mem., 156, 1-103, pls. $1-10$.

(1981): Triassic ammonoidea: Classification, evolution and relationship with Permian and Jurassic forms. In House, M. R. and SENIOR, J. R. (eds.): The Ammonoidea-The evolution, classification, mode of life and geological usefulness of a major fossil group-. Syst. Assoc. Spec., 18, 593 p., Academic Press, London. and PARKER, J. R. (1968): Notes on the Triassic biostratigraphy of Svalbard. Geol. Mag., 105, (6), 526-542, pIs. 25-27.

WAAgen, W. (1895): Fossils from the Ceratite Formation. Geol. Surv. India, Mem., Palaeont. Indica, [13], Salt Range Fossils, 2, 1-323, pls. 1-40. 